\title{
NEGROS DA TERRA E/OU NEGROS DA GUINÉ: TRABALHO, RESISTÊNCIA E REPRESSÃO NO GRÃO-PARÁ NO PERÍODO DO DIRETÓRIO
}

\author{
José Alves de Souza Junior*
}

$\mathrm{P}$

onto culminante da política indigenista pombalina, a instituição do regime do Diretório representou a completa laicização da administração das povoações indígenas existentes no estado do Grão-Pará e Maranhão. A partir da ideia recorrente entre os colonizadores da incapacidade dos índios de gerir seus próprios interesses, devido à rusticidade e ignorância de que são portadores, decidiu-se pela necessidade da presença, em cada povoação, de um diretor, que seria nomeado pelo governador do estado. ${ }^{1}$

A restauração da tutela era uma resposta à questão suscitada pela deserção em massa dos índios dos aldeamentos, quando a Lei de 1755 a suprimiu, ${ }^{2}$ e um modo de mantê-los nos mesmos, como mão de obra disponível aos moradores. Ao mesmo tempo, o Diretório estimulava a distribuição dos índios por lavouras familiares, nas quais realizariam uma produção de subsistência e de excedentes, já que a questão do tra-

Professor da Universidade Federal do Pará. E-mail: jalves@ufpa.br

Diretório, que se deve observar nas Povoações dos Índios do Pará, e Maranhão em quanto Sua Majestade não mandar o contrário, apud: Carlos de Araujo Moreira Neto, Índios da Amazônia. De maioria à minoria 1750-1850. Petrópolis: Editora Vozes, 1988, Apêndice Documental, pp. 165-205.

Lei de 6 de junho de 1755. Apud Moreira Neto, Índios da Amazônia, p. 156. Rita Heloísa de Almeida, O Diretório dos Índios: um projeto de civilização no Brasil do século XVIII. Brasília: Editora Universidade de Brasília, 1997, p. 167. 
balho vinculava-se à do comércio. ${ }^{3} \mathrm{O}$ objetivo era estimulá-los ao sedentarismo, o que demonstra ser o Diretório também um plano de povoamento do território.

Nesse sentido, a prioridade do Diretório era integrar os índios à civilização ocidental e, desse modo, garantir a efetiva ocupação do território colonial, preocupação esta que remonta aos primeiros monarcas portugueses ligados ao processo de colonização do Brasil. ${ }^{4}$ Alguns historiadores desenvolveram o pressuposto de que o aumento do poder do monarca estava relacionado com a quantidade de súditos sobre os quais tal poder era exercido, principalmente sobre aqueles economicamente produtivos, vinculando crescimento demográfico e desenvolvimento econômico. ${ }^{5}$

Na lógica do Diretório, a inserção dos índios na civilização seria feita também por meio do trabalho, o que exigiria a interiorização por eles da disciplina de tempo e de trabalho imposta pelos portugueses. Assim, "o Diretório dos Índios resumia a legislação aplicada primeiramente à Amazônia, visando a normatizar a relação entre o europeu e o ameríndio", distanciando-se da legislação indigenista anterior que delegava "aos religiosos a organização e a administração das povoações indígenas e a responsabilidade por inseri-los no âmbito da civilização", colocando-as "sob a égide do Estado". ${ }^{6}$

\footnotetext{
Mauro Cezar Coelho, "A Civilização da Amazônia - Alexandre Rodrigues Ferreira e o Diretório dos Î́ndios: a educação de indígenas e luso-brasileiros pela ótica do trabalho", Revista de História Regional, v. 5, n. 2 (2000), pp. 149-74, p. 159.

4 Maria Luiza Marcílio, "A população do Brasil colonial, in Leslie Bethell (org.), História da América Latina (São Paulo/Brasília: Edusp/Fundação Alexandre Gusmão, 1998), vol. II, pp. 311-38, p. 321.

5 Johannes Overbeek, Histoire de las teorias demográficas, México: FCE, 1984, pp. 44-51; J. Overbeek, "Mercantilism, Physiocracy and Population Theory", The south African Journal of Economics, v. 41, n. 2 (1973), pp. 167-73; Philip Kraeger, "Early Modern Population Theory: A Reassessment", Population and Development Review, v. 17, n. 2 (1991), pp. 20727; Jean-Claude Perrot, Une histoire intelectuelle de l'économie politique. XVII-XVIII siècle, Paris: Éditions EHESS, 1992, pp. 143-62; René Gonnard, Histoire des doctrines de la population, Paris: Nouvelle Libraire Nationale, 1923, pp. 89-90; Joseph J. Spengler, "History of Population Theories", in Julian L. Simon (org.), The Economics of Population: Classic Writings (New Brunswick: Transaction Publishers, 1998), pp. 207-27.

6 Coelho, "A civilização da Amazônia", p. 151. Essa também é a tese defendida por Almeida, $O$ diretório dos índios, 1997.
} 
Além disso, o Regimento do Diretório tornou-se a estrutura legislativa que alicerçou o projeto de civilização desenvolvido pelo Estado português na Amazônia e, depois, em toda a Colônia, cujo objetivo maior era "a transformação dos ameríndios em vassalos portugueses e católicos fiéis". Desse modo, a política pombalina, no que dizia respeito à presença colonizadora luso-brasileira na Amazônia, foi pensada a partir de três pressupostos: "os casamentos mistos entre lusobrasileiros e índias; a educação e o ensino da língua portuguesa a todas as camadas da população; e o desenvolvimento econômico"?

Francisco Jorge dos Santos, ao estudar as relações sociais tecidas pelos diversos sujeitos sociais no ambiente criado pela legislação do Diretório, chama a atenção para o fato de que, apesar de se desenvolverem ligadas ao objetivo mercantil da colonização, tais relações resultavam do encontro entre a política indigenista colonial e a política formulada pelos índios ante a situação histórica que lhes foi imposta. ${ }^{8} \mathrm{Ou}$ seja, vivenciavam e pensavam suas experiências cotidianas nas relações com os invasores, como atores de sua história.

Embora não tenha introduzido a exploração do trabalho indígena, ${ }^{9}$ o Diretório buscou organizá-la sob outros moldes, daí a necessidade da instituição de uma nova regulamentação, que procurava evitar a vadiagem. ${ }^{10}$ No sentido de disciplinar a utilização do trabalho dos índios, o Regimento do Diretório estabeleceu que caberia aos principais das aldeias a distribuição dos índios entre os moradores, que, ao requererem, deveriam apresentar portarias do governador do Estado. ${ }^{11}$

Ao invés de divididos em três partes, como antes, os índios seri-

\footnotetext{
Ângela Domingues, Quando os índios eram vassalos: colonização e relações de poder no Norte do Brasil na segunda metade do século XVIII, Lisboa: Comissão Nacional para as Comemorações dos Descobrimentos Portugueses, 2000, pp. 65 - 6.

8 Francisco Jorge dos Santos, Além da Conquista: guerras e rebeliões indígenas na Amazônia pombalina, Manaus: Editora da Universidade do Amazonas, 1999, pp. 45-65.

9 Farage aponta que a exploração do trabalho indígena existiu na Colônia muito antes da implantação do Diretório e que este não foi criado com o objetivo de justificá-la. Nesse sentido, considera que a exploração foi um elemento constitutivo da colonização, na forma como ela foi instituída pelos portugueses no Brasil. Nádia Farage, As muralhas dos sertões: os povos indígenas o Rio Branco e a colonização, Rio de Janeiro: Paz e Terra: ANPOCS, 1991, p. 41 e 47.

${ }^{10}$ Farage, As muralhas dos sertões.

11 Diretório, p. 192.
} 
am separados em duas partes iguais, devendo uma se conservar nas suas respectivas povoações, para garantir a defesa do Estado e estar disponível ao Real serviço, e outra seria destinada à repartição entre os moradores, "não só para a equipagem das Canoas, que vão extrair Drogas do Sertão, mas para os ajudarem na plantação dos Tabacos, canas de Açúcar, Algodão, e todos os gêneros, que podem enriquecer o Estado, e aumentar o Comércio". ${ }^{12}$

Eram considerados aptos ao trabalho todos os índios entre treze e sessenta anos, ${ }^{13}$ que seriam matriculados em dois livros rubricados pelo desembargador juiz de Fora, em cujo poder ficaria um dos livros, sendo o outro entregue ao governador, devendo ser tais listas atualizadas anualmente. O prazo de utilização do trabalho indígena era de seis meses, mediante o pagamento de salários, que deveriam ser depositados integralmente nas mãos do diretor da povoação no momento do recebimento do lote de trabalhadores. ${ }^{14}$

Apesar da imposição do pagamento de salários aos índios ter sido uma constante na legislação, dificilmente isso acontecia, pois os colonos encontravam inúmeras formas de burlar a legislação e utilizá-los como escravos..$^{15}$ Por isso, o pagamento antecipado procurava prevenir esta possibilidade, mas provocava clamores de descontentamento entre os colonos que alegavam sofrer grandes prejuízos, devido às constantes fugas dos índios de suas lavouras antes de se completarem os seis meses de trabalho devidos.

Para solucionar tal impasse, o Regimento estabeleceu que o diretor só repassasse aos índios $1 / 3$ do salário a que tinham direito, ficando os outros $2 / 3$ depositados num cofre na povoação para serem pagos ao

12 Diretório..., p. 192. Sobre a agricultura, desde o século XVII, ir assumindo um papel central no pensamento português acerca da ocupação da terra nas conquistas ver: Rafael Chambouleyron, Povoamento, ocupação e agricultura na Amazônia Colonial (1640-1706), Belém: Ed. Açaí/Programa de Pós-Graduação em História Social da Amazônia (UFPA)/Centro de Memória da Amazônia (UFPA), 2010, pp. 121-69.

13 Ângela Domingues indica que a faixa etária dos índios dos aldeamentos que deveriam ser repartidos em três grupos para o trabalho, de 1686 até as reformas empreendidas por Mendonça Furtado, era de 15 a 60 anos. Domingues, Quando os índios eram vassalos, p. 178.

14 Diretório, pp. 192-3.

15 Domingues, Quando os índios eram vassalos, pp. 178-9. 
final do trabalho. Em caso de fuga antes do cumprimento do prazo de trabalho previsto, os $2 / 3 \mathrm{em}$ depósito seriam devolvidos ao morador prejudicado, isto se a fuga não tivesse sido motivada por ele. No entanto, se a fuga tivesse sido por maltrato ou outro qualquer motivo por parte do morador, este, além de perder o valor depositado, pagaria o dobro dele aos índios envolvidos no caso. Assim, tentava-se garantir aos índios estímulo para trabalhar nas lavouras e nas expedições ao sertão, reduzindo-se as fugas e atenuando-se a resistência ao trabalho. ${ }^{16}$

A violência que marcou as relações de trabalho entre índios e colonos tornava pouco eficiente os estímulos previstos no Regimento do Diretório para convencê-los das "vantagens" de trabalhar para os moradores. A exploração excessiva a que comumente eram submetidos tornava-os arredios ao trabalho e levava-os a constantes fugas. A secularização dos aldeamentos não foi bem recebida pelos indígenas, pois os colocava diretamente à mercê dos colonos e das autoridades locais, além de ser o diretor que os tutelava, quase sempre, tirado do meio dos brancos.

\section{Trabalho, epidemias e resistência: índios trabalhadores $\mathrm{X}$ índios agricultores}

A dependência dos moradores da mão de obra indígena, segundo Domingues, seria "intrínseca à organização econômica e social no Norte brasileiro". ${ }^{17}$ A ocupação econômica da Amazônia colonial, iniciada nos primórdios dos Seiscentos, se desenvolveu em torno de atividades agrícolas, extrativistas e criatórias, para cuja realização o trabalho indígena era indispensável. ${ }^{18}$

\footnotetext{
6 Diretório, pp. 194-95.

Domingues, Quando os índios eram vassalos, p. 177.

18 Embora reconheça que, para o século XVII, nada indique a existência de uma reflexão sistemática sobre o papel da agricultura como meio de ocupação das capitanias do Norte na historiografia portuguesa, Chambouleyron considera que "a recorrência dessa questão nos escritos enviados à Corte e nas ações da própria Coroa indica como a ocupação econômica da terra, por meio da atividade agro-pastoril, efetivada pelos "povoadores" e "habitadores", se tornara uma lente através da qual se compreendia o mundo que se construía no estado do Maranhão e Grão-Pará”. Rafael Chambouleyron, Povoamento, ocupação e agricultura na Amazônia Colonial (1640-1706), Belém: Ed. Açaí/Programa de Pós-Graduação em História Social da Amazônia (UFPA)/Centro de Memória da Amazônia (UFPA), 2010, p. 121.
} 
Nas capitanias afastadas do nordeste açucareiro, alvo central do tráfico negreiro durante os dois primeiros séculos da colonização, o trabalho indígena assumiu uma importância fundamental para a sobrevivência dos colonos. Na Amazônia, a grande densidade demográfica indígena, principalmente na área da Várzea, via de penetração da colonização, colocou à disposição dos colonos leigos e eclesiásticos um imenso contingente de trabalhadores, cuja reprodução estaria garantida pela quantidade existente. ${ }^{19}$

O trabalho indígena era utilizado em múltiplas atividades por moradores, missionários e autoridades coloniais, que disputavam o controle dessa mão de obra. Se na Corte essa disputa girava em torno da obtenção de leis que beneficiassem aos contendores, na Amazônia assumia formas bem mais radicais, materializando-se em confronto aberto. ${ }^{20}$ Os abusos e maus tratos sofridos pelos índios nas suas lidas diárias, quer em trabalhos privados, quer públicos, são atestados tanto na documentação como na historiografia. ${ }^{21}$

A concorrência representada pela utilização de índios nos serviços públicos incomodava profundamente os colonos, que consideravam tal uso um desperdício. Por isso, defendiam a introdução de escravos africanos no estado à custa da Fazenda Real, para serem ocupados em trabalhos públicos ao invés de neles se utilizarem índios, o que viam como mais proveitoso para o aumento das capitanias da região. Nesse sentido, os representantes da Companhia de Comércio do Maranhão apresentaram à Coroa portuguesa, em 1703, uma exposição de motivos em que protestavam contra o emprego de 400 índios no serviço do Ar-

19 Os estudos de demografia histórica realizados por William Denevan, na década de 1970, apontam para a Amazônia Continental uma população de mais de cinco milhões de habitantes. William M. Denevan, The Native Population of the Americas in 1492, Madison: University of Wisconsin, 1992, p. 205 e ss.

20 Arenz analisa os dois momentos em que os jesuítas foram expulsos do estado do Maranhão e Pará pelos moradores e que correspondem aos anos de 1661 e 1684. Karl-Heins Arenz, De l'Alzette à l'Amazone. Jean-Philippe Bettendorff et les jésuites em Amazonie portugaise (16611693), Sarrebruck: Éditions universitaires européennes, 2010, pp. 103-05, 371-87.

21 Domingues, Quando os índios eram vassalos, pp. 177-89; John Hemming, Ouro vermelho: a conquista dos índios brasileiros, São Paulo: Edusp, 2007, pp. 589-614. Quanto à documentação que indica serem os índios vítimas de abusos e maus tratos, veremos no desenrolar do artigo. 
senal de Marinha, demonstrando, com base num raciocínio pleno de racionalidade econômica, o grande desperdício que isso significava. ${ }^{22}$ O emprego da mão de obra indígena pelas autoridades coloniais na construção e na condução de barcos decorria da opinião generalizada de que os índios tinham aptidões naturais para a navegação, opinião que se manteve até o Primeiro Reinado, haja vista o intenso recrutamento de índios para o Arsenal de Marinha da Corte. ${ }^{23}$

O documento dos representantes da Companhia de Comércio do Maranhão nos permite entrever um dos motivos mais importantes da preferência dos moradores pelos trabalhadores índios: a coleta das drogas do sertão. Esta era uma das principais atividades econômicas da Amazônia colonial, pois as drogas do sertão, produtos silvestres, como cacau, salsaparrilha, pau-cravo, bálsamo de copaíba, baunilha, canela, anil, urucum, raízes aromáticas e sementes oleaginosas, obtinham excelentes preços no mercado europeu, o que tornava o seu comércio extremamente lucrativo. ${ }^{24}$

A coleta desses produtos silvestres exigia um conhecimento da floresta que só os índios possuíam, o que tornava, especificamente nessa atividade econômica, o trabalho africano inócuo. Desse modo, a dependência dos moradores leigos e eclesiásticos em relação a esse saber venatório dominado pelos índios era imensa, ${ }^{25}$ pois os utilizavam também como caçadores, remadores, guias pelos caminhos da floresta, sendo tal dependência agravada pelo gigantismo da região e pela não aclimatação à floresta, como havia acontecido com os sertanistas paulistas. ${ }^{26}$

Na segunda metade do século XVIII ocorreu uma rearticulação dos meios de acesso à mão de obra indígena, na medida que a interven-

\footnotetext{
2 Hemming, Ouro vermelho.

${ }^{23}$ Manuela Carneiro da Cunha, "Política indigenista no século XIX", in Manuela C. da Cunha (org.), História dos índios no Brasil (São Paulo: Companhia das Letras: Secretaria Municipal de Cultura/ FAPESP, 1992), pp. 133-54, p. 150

${ }^{24}$ Para um extenso inventário sobre as riquezas da Amazônia, ver: João Daniel, Tesouro descoberto no máximo rio Amazonas, v. 1 e 2. Rio de Janeiro: Contraponto, 2004.

${ }^{25}$ Carlo Ginzburg, Mitos. Emblemas e sinais: morfologia e história; São Paulo: Companhia das Letras, 1989, pp. 143-79.

${ }^{26}$ Sérgio Buarque de Holanda, Caminhos e fronteiras, Rio de Janeiro: Livraria José Olympio Editora, 1957.
} 
ção pombalina no processo de colonização produziu um novo contexto histórico na Amazônia colonial. Desse novo contexto fizeram parte a colocação em vigor da Lei da Liberdade dos Índios de 1755, que, entre outras coisas, abolia completamente a escravidão indígena e extinguia o poder temporal dos missionários sobre os índios; o estabelecimento da Companhia Geral de Comércio do Grão-Pará e Maranhão, que recebeu o estanco do comércio e a obrigação de introduzir escravos africanos por preços moderados no estado; a implantação do Diretório dos Índios, que os colocou sob a tutela direta do Estado, representada pelos diretores das povoações, antigos aldeamentos.

Ao mesmo tempo, a assinatura do Tratado de Madri, em 1750, que redefinia as fronteiras dos domínios luso-espanhóis na América do Sul, exigia a efetiva ocupação da região Norte, sempre carente de povoadores brancos. Nesse sentido, o governo josefino intensificou o envio de colonos ilhéus, reinóis e mazaganistas, degredados e soldados, o que aumentou as pressões por trabalho indígena. Além disso, os proprietários de terra locais procuravam manter os trabalhadores índios que até então tinham sido seus escravos, com o argumento de que não possuíam cabedais para comprar os escravos africanos vendidos pela companhia de comércio. ${ }^{27}$

Desse modo, segundo Ângela Domingues, na segunda metade do século XVIII, a arregimentação de mão de obra indígena tinha que ser conciliada,

com uma série de novas realidades: a proclamação da liberdade dos indígenas e reconhecimento da posse de bens, a mudança da autoridade tutelar indígena de missionários para governador e diretores; a prioridade em ocupar e colonizar os limites do Estado; o prevalecimento dos serviços da Coroa e das demarcações; e a necessidade de, acima de tudo, se manter a paz e a estabilidade internas. ${ }^{28}$

Tais modificações introduzidas no mundo do trabalho amazônico

\footnotetext{
27 Domingues, Quando os índios eram vassalos, p. 179. Sobre as ações da Coroa portuguesa para ocupar tão vasto território no século XVII, ver Chambouleyron, Povoamento, ocupação e agricultura na Amazônia Colonial, pp. 29-76.

28 Domingues, Quando os índios eram vassalos, p. 177.
} 
provocaram a ampliação das formas de resistência indígena à colonização, pois, além das tradicionais, como as fugas individuais ou coletivas e as revoltas, a nova legislação indigenista colocou à disposição dos índios dispositivos legais por meio dos quais podiam fazer petições às autoridades e inclusive ao rei, denunciando as arbitrariedades e abusos que sofriam. Apesar do multifacetamento sofrido pela resistência indígena, as fugas, denominadas na documentação de "deserções", teriam sido a forma mais usual. As fugas envolviam ações "individuais, de pequenos grupos e de povoações inteiras ou, até, de núcleos de aldeamento em cadeia" ${ }^{29}$

\section{Lei de 1755: faca de dois gumes}

Embora sua intenção fosse estimular os índios a tornarem-se trabalhadores assalariados, ao proibir a sua escravização, a Lei da Liberdade dos Índios de 1755 teve como um dos seus resultados o esvaziamento das povoações, pois os índios, apropriando-se e reelaborando o teor de lei, não se sentiam mais na obrigação de continuar nelas. A intensificação das fugas causava grande preocupação às autoridades coloniais que, em seus informes, queixavam-se do prejuízo que elas provocavam, pois "a falta de Índios tem reduzido aos moradores desta terra no mais deplorável estado". ${ }^{30} \mathrm{O}$ problema parece ter sido recorrente durante todo o período de vigência do Diretório.

A associação entre a intensificação das fugas e a liberdade concedida aos índios foi recorrente na correspondência mantida pelas autoridades coloniais com a Metrópole. Exemplo disso foi o ofício enviado à Corte pelo governador Manuel Bernardo de Melo e Castro, em agosto de 1759, no qual informava "o lastimoso estado a que estão reduzidas as Povoações desta Capitania [do Pará] achando-se todas elas evacuadas de Índios", ${ }^{11}$ considerando que o motivo dessa situação era a alforria concedida aos mesmos pela Lei de 1755 .

\footnotetext{
29 Domingues, Quando os índios eram vassalos, p. 257.

${ }^{30}$ Ofício de João Vieira Lemos para o governador e capitão-general do Estado do Grão-Pará e Maranhão, Manuel Bernardo de Melo e Castro, 20/04/1759. Arquivo Público do Estado do Pará (APEP), Códice 95: Correspondência de Diversos com o Governo. Ano de 1759, Doc. 20, p. 46. 31 Ofício do governador e capitão-general do Estado do Grão-Pará e Maranhão, Manuel Bernardo de Melo e Castro, para o [capitão-general] Francisco Xavier de Mendonça Furtado, 09/08/ 1759, Arquivo Histórico Ultramarino (AHU), Pará (Avulsos), Cx. 45, D. 4106.
} 
O campeão nesse tipo de queixa foi o governador João Pereira Caldas. Em março de 1773, mais de vinte anos depois do ofício de Manuel Bernardo de Melo e Castro, recolocava o problema a Martinho de Melo e Castro, secretário de Estado da Marinha e Ultramar, informando que "a diminuição de índios que achei nestas Povoações é tão considerável, que [...] me faltam até os necessários para o ordinário serviço Real, em que absolutamente se fazem indispensáveis". ${ }^{32}$

No mês seguinte, referia-se à "deplorável ruína, e diminuição de índios, a que se acham reduzidas todas as suas Povoações", indicando que o motivo de tanta deserção era serem os índios forçados "em tantos trabalhos, e serviços superiores às possibilidades deste Estado". ${ }^{33}$

Em julho, demonstrava preocupações com a situação dos moradores do estado, pois "não havendo já índios nas Povoações, que possam ser repartidos pelos moradores, como se fazia todos os anos, para a colheita daqueles gêneros, que fazem os principais ramos do Comercio deste Estado". ${ }^{34}$ No ano de 1775 , informava que o esvaziamento das povoações se devia não só à deserção dos índios, mas também à "mortandade [...] pelos repetidos contágios de bexigas, e sarampos". ${ }^{35}$ Três anos depois o problema parece ter persistido e se agravado pela dificuldade de fazer novos descimentos, devido à resistência dos índios, pois, "quando alguns se resolvem a descer, só querem fazer, para as vizinhanças das suas habitações, para onde finalmente se tornam a recolher recebidas as assistências, com que lhes costuma contribuir pela Real Fazenda". ${ }^{36}$

\footnotetext{
32 Ofício do governador e capitão-general do Estado do Grão-Pará e Maranhão, João Pereira Caldas, para o [secretário de Estado da Marinha e Ultramar], Martinho de Melo e Castro, $07 /$ 03/1773, AHU, Pará (Avulsos), Cx. 70, D. 5964.

33 Ofício do governador e capitão-general do Estado do Grão-Pará e Maranhão, João Pereira Caldas, para o [secretário de Estado da Marinha e Ultramar], Martinho de Melo e Castro, 07/ 04/1773, AHU, Pará (Avulsos), Cx. 70, D. 5993.

${ }^{34}$ Ofício do governador e capitão-general do Estado do Grão-Pará e Maranhão, João Pereira Caldas, para o [secretário de Estado da Marinha e Ultramar], Martinho de Melo e Castro, 29/ 07/1773, AHU, Pará (Avulsos), Cx. 71, D. 6033.

35 Ofício do governador e capitão-general do Estado do Grão-Pará e Maranhão, João Pereira Caldas, para o [secretário de Estado da Marinha e Ultramar], Martinho de Melo e Castro, 06/ 11/1775, AHU, Pará (Avulsos), Cx. 74, D. 6249.

36 Ofício do governador e capitão-general do Estado do Grão-Pará e Maranhão, João Pereira Caldas, para o [secretário de Estado da Marinha e Ultramar], Martinho de Melo e Castro, 10/ 08/1778, Arquivo Histórico Ultramarino (AHU) Pará (Avulsos), Cx. 80, D. 6623.
} 
Nos ofícios do governador João Pereira Caldas, podemos visualizar algumas das causas do esvaziamento das povoações: a rejeição pelos índios da disciplina de tempo e de trabalho imposta pelos colonizadores; o contágio de bexigas; a recusa em fazer descimentos. É claro que muitos outros motivos causavam suas fugas, que também podiam ser

uma expressão do seu desacordo contra o processo de aculturação desenvolvido pelas autoridades administrativas e religiosas luso-brasileiras; contra as fomes que, por vezes, grassavam durante um ano de más colheitas agrícolas ou em locais de recente fixação e, por isso, ainda não cultivados. ${ }^{37}$

Evidências empíricas confirmam e ampliam as hipóteses trabalhadas acima. Na vila de Portel, o que levou a "se acharem refugiados no mato os moradores desta Povoação", foi o temor "das bexigas que constantemente os tem perseguido". ${ }^{38}$ Na vila de Souzel, os "moradores [andam] dispersos pela necessidade de mantimentos". ${ }^{39} \mathrm{Na}$ de Veiros, o rigor com que o padre vigário tratava índios e índias resultou "em que tem ausentado quatro casais de índios com suas famílias". ${ }^{40} \mathrm{O}$ assédio sexual do diretor da vila de Pinhal "a duas mulheres de dois soldados [...] [foi a causa de] irem fugidas para o mato". ${ }^{41}$

Além disso, as fugas também eram atribuídas às más práticas de principais e oficiais índios, que as estimulavam e acoitavam os fugitivos em seus sítios. As arbitrariedades dos diretores também motivavam

\footnotetext{
37 Domingues, Quando os índios eram vassalos, p. 256.

38 Ofício do diretor da Vila de Portel, José da Silva Senna, para o governador e capitão-general do Estado do Grão-Pará e Maranhão, Manuel Bernardo de Melo e Castro, 10/04/1759, APEP, Códice 95: Correspondência de Diversos com o Governo. Ano de 1759, Doc. 16, p. 36.

39 Ofício do diretor da Vila de Souzel, Cosme Damião da Silva, para o governador e capitãogeneral do Estado do Grão-Pará e Maranhão, Manuel Bernardo de Melo e Castro, 30/06/1759, APEP, Códice 95: Correspondência de Diversos com o Governo. Ano de 1759, Doc. 77, p. 224.

40 Ofício do diretor da Vila de Veiros, Antônio Francisco Lemos, para o governador e capitãogeneral do Estado do Grão-Pará e Maranhão, Manuel Bernardo de Melo e Castro, 20/07/ 1759, APEP, Códice 95: Correspondência de Diversos com o Governo. Ano de 1759, Doc. 92 , p. 274.

41 Ofício do diretor da Vila de Pinhal, Antônio José Duarte da Silva, para o governador e capitão-general do Estado do Grão-Pará e Maranhão, Manuel Bernardo de Melo e Castro, 09/04/ 1761, APEP, Códice 106: Correspondência de Diversos com o Governo. Ano de 1761, Doc. 9 , p. 24.
} 
fugas, sendo este o motivo "porque fugiram cinquenta, e tantas pessoas para o mato, e entre estas 14 índios do serviço, e se presumia que enquanto não houvesse troca de Diretor se não recolheriam à Povoação". ${ }^{42}$

No entanto, a motivação campeã para as fugas era a aversão dos índios à disciplina de tempo e de trabalho que lhes estava sendo imposta, de uma forma mais sistemática a partir da instituição do Diretório. Esta aversão era atribuída pelos colonizadores ao fato de serem os índios, por natureza preguiçosos, afeitos à ociosidade, desprovidos de qualquer ambição. Essa concepção sobre os índios era confirmada pelo governador João Pereira Caldas:

Trabalhando-se, porém, há tempo bastante no adiantamento do mesmo Estado, ele justamente iria já melhor correspondendo a tantas fadigas, e despesas, se o desmazelo, e bem reconhecida preguiça destes habitantes, não dificultassem os desvelos com que se lhes procura a sua própria felicidade, e este achaque, e o de uma total falta de ambição, para o em que licita, e [por] louvável se deve ter, são tanto mais inseparáveis de todos os índios, que absolutamente não há modo de os persuadir ao seu bem; nem de os animar ao trabalho, de que eles nada gostam, ainda quando estão vendo ser seu o proveito, e que os seus interesses se fazem contemplar com a maior exação, tanto nos jornais, que vencem, como no embolso do produto dos seus efeitos. ${ }^{43}$

A realidade, porém, era outra, pois, comumente, o papel de índio agricultor, que iria trabalhar para o seu sustento, era incompatível com o de índio trabalhador, papel principal destinado a eles pelo Diretório dos Índios. A contínua redução das populações das povoações, pelo grande número de deserções, impossibilitava as autoridades coloniais, mesmo que estivessem dispostas, de cumprir os parágrafos do Regimento do Diretório, que normatizavam a utilização do trabalho indígena, principalmente o que determinava a rendição dos índios repartidos aos colonos de seis em seis meses.

42 Auto da Devassa tirada na Vila de Faro, 06/01/1769, APEP, Códice 160: Devassas. 17651769, Doc. s/n.

${ }^{43}$ Ofício do governador e capitão-general do Estado do Grão-Pará e Maranhão, João Pereira Caldas, para o [secretário de Estado da Marinha e Ultramar], Martinho de Melo e Castro, 06/ 11/1775, AHU, Pará (Avulsos), Cx. 74, D. 6249. 


\section{Índios: "mãos e pés dos senhores" da Amazônia}

A sobreposição do papel de índio trabalhador ao de índio agricultor fica clara na definição, pelo Regimento, "dos Índios capazes de trabalho", que seriam todos que estivessem na faixa etária de 13 a 60 anos. ${ }^{44} \mathrm{O}$ regime de trabalho imposto aos índios, que os condenava a viver para trabalhar, contrariava a sua "economia moral", ${ }^{45}$ segundo a qual o tempo de trabalho realizado deveria prover a sobrevivência. Como bem demonstrou Thompson, a luta de classes é também uma luta acerca de valores. ${ }^{46}$

A correspondência dos governadores do estado com a Metrópole, que aponta para a priorização da utilização da mão de obra indígena nos serviços reais e nos serviços de particulares, e para as dificuldades de se render os trabalhadores índios de seis em seis meses, devido à contínua redução das populações das povoações, é abundante. Alguns exemplos são bem elucidativos dessas questões. Em 1761, o governador Manuel Bernardo de Melo e Castro considerava que:

[...] de maior dano para o Real serviço, o não terem as Povoações outros tantos índios, como os que estiverem ocupados para se mudarem de seis em seis meses vindo por esta razão a serem atuais, e contínuos no dito ministério, sem que em todo o ano possam ir fazer as suas roças, aumentar as plantações, e extrair os efeitos do Sertão. ${ }^{47}$

Em 1773, o então governador João Pereira Caldas, invertendo a lógica da exposição de motivos dos oficiais da Câmara de São Luís, vista anteriormente, propunha utilizar a mão de obra indígena apenas nos serviços reais, poupando-os do exaustivo trabalho nas lavouras dos colonos. Estes deveriam ser supridos de escravos africanos a preços módicos. Argumentava Caldas que:

${ }^{44}$ Diretório que se deve, Parágrafos 59-73.

45 Para a rejeição dos novos valores impostos pelo Capitalismo aos trabalhadores num outro contexto ver: Edward Palmer Thompson, Costumes em comum, São Paulo: Companhia das Letras, 1998, pp. 150-202.

46 Edward P. Thompson, A miséria da teoria ou um planetário de erros: uma crítica ao pensamento de Althusser, Rio de Janeiro: Zahar Editores, 1981, pp. 189-90.

47 Ofício do governador e capitão-general do Estado do Grão-Pará e Maranhão, Manuel Bernardo de Melo e Castro, para o [secretário de Estado da Marinha e Ultramar], Francisco Xavier de Mendonça Furtado, 26/06/1761, AHU, Pará (Avulsos), Cx. 49, D. 4519. 
indispensavelmente são precisos atuais no Real serviço, por não terem as Povoações o número, que permita o rende-los de seis em seis meses; estive cogitando o meio de fazer possível este trabalho, sem se seguir o forçoso dano às Povoações, de que se hão de tirar os índios, que se hão de empregar nos cortes, e conduções das madeiras, para a fábrica da Nau, e mais charruas, que S. Maj. determina mandar continuar, em conduzir para o Arsenal dessa Corte. ${ }^{48}$

Ainda no ano de 1773, o referido governador, em um bando encaminhado aos diretores das povoações, alertava para a gravidade do problema das deserções dos índios causado pela frequente extrapolação do tempo máximo de seis meses a serviço de particulares. Alertava também que tais fugitivos, além de passarem a se "sustentar com furtos [...], promoviam outras muitas desordens nas roças e Povoações [...]”, que prejudicavam, imensamente, "ao serviço de Deus, e de S.Maj.". Argumentava, ainda, que:

Um destes motivos, que naturalmente os fazem abandonar as suas Casas, e famílias, nas Povoações [é porque] desamparam as suas habitações, por mais tempo do que lhe é permitido; e são estes aqueles que sendo dados por Portarias a Moradores por algum tempo, para os ajudarem às suas culturas, e lavouras, os demoram, e eternizam no seu serviço, excedendo muito o tempo das suas respectivas concessões em dano considerável do Estado. ${ }^{49}$

O resultado mais visível de tais práticas era a o desabastecimento das povoações e as crises de fome enfrentadas por suas populações. $\mathrm{O}$ próprio Regimento do Diretório atesta isto no seu parágrafo 21, quando se refere à escassez de farinha nas povoações nos anos de 1754 e 1755 , que "as pessoas pobres, e miseráveis, se viam precisadas a buscar nas frutas silvestres do mato o cotidiano sustento com evidente perigo das próprias vidas". ${ }^{50}$

\footnotetext{
48 Ofício do governador e capitão-general do Estado do Grão-Pará e Maranhão, João Pereira Caldas, para o [secretário de Estado da Marinha e Ultramar], Martinho de Melo e Castro, $07 /$ 04/1773, AHU, Pará (Avulsos), Cx. 70, D. 5993.

49 Bando dado nesta Cidade de Belém pelo governador e capitão-general João Pereira Caldas, aos vinte e três dias do mês de Maio do Ano do Nascimento de Nosso Senhor Jesus Cristo de mil setecentos e setenta e três. Anexo do Ofício do governador e capitão-general do Estado do Pará e Rio Negro, João Pereira Caldas, para o secretário de Estado da Marinha e Ultramar, Martinho de Melo e Castro, 29/07/1773, AHU, Pará (Avulsos), Cx. 71, D. 6032.

${ }^{50}$ Diretório que se deve.
} 
O diretor da vila de Salvaterra, Raimundo José de Betencourt, informava a falta de farinha na vila, alegando que "a causa é o ter andado a maior parte deles [dos índios] dispersos por serviços [...], e não se recolherem a tempo de fazerem suas roças". ${ }^{51}$ O Principal da mesma vila, Xavier de Mendonça, justificava ao governador "não ter mandado o provimento a essa cidade [Belém] pela razão da maior parte dos índios andarem no serviço de S. Maj. e dos moradores". ${ }^{52}$ Em Santarém, quando da devassa tirada, o ouvidor-geral informava que

queixam-se os índios todos daquela Vila da grande necessidade que experimentam de farinha para o seu cotidiano sustento, morrendo todos de fome, e o mais é o ficarem sem roças no ano presente por não conseguirem licença do Diretor para as irem beneficiar, fazendo-os estar efetivamente na Vila ocupando a todos no serviço da olaria. ${ }^{53}$

Descontando-se os prováveis exageros cometidos pelos índios para comprometer o diretor, é possível constatar que a exploração da mão de obra indígena foi intensificada com a implantação do Diretório dos Índios. Os "Reais serviços" absorviam a maior parte destes trabalhadores. Só a título de exemplo, em 1766, 33 índios fugiram de fábricas instaladas em várias vilas, sendo 12 da de Portel, 6 da do Acará, 5 da de Colares, 2 da de Vila Nova d'El Rei, 7 da capitania do Maranhão e 1 da de Salvaterra. ${ }^{54}$ Na Fábrica Real do rio Acará, em 1792, trabalhavam 95 índios. ${ }^{55}$ Dois anos depois, a mesma fábrica recebia 50 índios, "a saber de Portel 30, de Melgaço 12, de Oeiras 8". ${ }^{56}$ Em setembro de

51 Ofício do diretor da Vila de Salvaterra, Raimundo José Betencourt, para o governador e capitãogeneral do Estado do Grão-Pará e Maranhão, Manuel Bernardo de Melo e Castro, 20/05/1759, APEP, Códice 95: Correspondência de Diversos com o Governo. Ano de 1759, Doc. 52, p. 147.

52 Ofício do Principal da Vila de Salvaterra, Xavier de Mendonça, para o governador e capitãogeneral do Estado do Grão-Pará e Maranhão, Manuel Bernardo de Melo e Castro, 21/05/1759, APEP, Códice 95: Correspondência de Diversos com o Governo. Ano de 1759, Doc. 53, p. 149.

53 Auto da Devassa tirada na Vila de Santarém, 30/01/1767, APEP, Códice 160: Devassas. 17651769, Doc. s/n.

54 Relação dos índios que têm fugido das Fábricas, APEP, Códice 76: Correspondência de Diversos com o Governo. 1753-1768, Doc. 41.

55 Ofício do administrador da Fábrica Real do rio Acará para o governador e capitão-general do Estado do Grão-Pará e Maranhão, D. Francisco de Souza Coutinho, 03/06/1792, APEP, Códice 83: Correspondência de Diversos com o Governo. 1754-1799, Doc. 35, p. 88.

56 Recibo de recebimento de cinquenta índios pela Fábrica Real do rio Acará, 28/01/1794, APEP, Códice 83: Correspondência de Diversos com o Governo. 1754-1799, Doc. 86, p. 214. 
1765, 346 trabalhadores estavam sendo utilizados em diferentes serviços relacionados à construção da Fortaleza de São José de Macapá, sendo 169 índios e 177 negros. $^{57}$

Os "serviços reais" não implicavam apenas em trabalho nas fábricas e construção de fortalezas, mas em diversas outras atividades, como, por exemplo, em contratos reais do corte das madeiras, do pesqueiro, dos dízimos, dos açougues, das galinhas para o Hospital Real de Macapá; como prático da Barra, como pescadores para destacamentos, militares, diretores, oficiais de povoações e vigários; no serviço de comércio para o Mato Grosso, ${ }^{58}$ onde foi estabelecida uma rota fluvial até o rio Amazonas, que subia os rios Guaporé, Mamoré e Madeira, e percorria centenas de quilômetros entre ilhas, pântanos e cachoeiras. ${ }^{59}$ No ano de 1774, dos 4.142 índios aptos ao trabalho presentes nas 54 povoações da capitania do Pará, 1.302 estavam empregados em serviços públicos e 214 "nos serviços dos Moradores". 60

Também os diretores tiravam imensos proveitos do trabalho dos índios, utilizando-os em serviços particulares e, assim, reduzindo em muito o tempo de trabalho em suas roças. Este foi o caso do diretor da vila de Veiros, Cosme Damião da Silva, denunciado na devassa por "oprimir aos índios castigando-os, mandando-os de um serviço para outro sem descansarem [...] e o pior é sem lhes pagar". ${ }^{61}$ A insatisfação dos índios ante essas situações era notada pelas autoridades coloniais, pois os mesmos deixavam claro

o desgosto com que olham o trabalho quando vêem que se lhes demora o tempo do descanso, ou ao menos o de poderem ir cultivar o sustento

57 Mapa do número dos Índios e Pretos trabalhadores que a 3 de Setembro do presente ano de 1765 se acham empregados em diferentes destinos respectivos à obra da Fortificação, APEP, Códice 61: Correspondência de Diversos com os Governadores. Ano de 1765. doc. 38.

58 Ângela Domingues fornece uma lista de serviços Reais em que os índios eram ocupados. Domingues, Quando os índios eram vassalos, p. 185.

59 Hemming, Ouro vermelho, p. 661.

${ }^{60}$ Mapa dos Oficiais, e mais índios das Povoações da Capitania do Grão Pará, capazes de serviço, e da distribuição em que existiam no fim de Junho de 1774. Anexo ao Ofício do governador e capitão-general do Estado do Pará e Rio Negro, João Pereira Caldas, para o secretário de Estado da Marinha e Ultramar, Martinho de Melo e Castro, 12/04/1775, AHU, Pará (Avulsos), Cx. 74, D. 6212.

${ }^{61}$ Auto da Devassa tirada na Vila de Veiros, 11/12/1764, APEP, Códice 160: Devassas. 17651769, Doc. s/n. 
para as suas mulheres, e filhos, e muitas vezes, ainda sem este motivo, fogem à violência da ocupação. ${ }^{62}$

À medida que as populações das povoações iam ficando cada vez mais rarefeitas, a pressão sobre a mão de obra indígena aumentava a ponto de os índios trabalharem forçados, já que, "segundo notícias, tem trabalhado em ferros, e separados das mulheres". ${ }^{63}$ Muitos eram mantidos no "Real serviço" por longos períodos, "e daqui procede que nele muitos se conservam efetivos, há três, quatro, cinco, e mais anos, por não haver outros, que os possam mudar, e substituir". Entre os serviços públicos, os mais rejeitados pelos índios eram as expedições à capitania do Mato Grosso, que "tem acabado uma grande parte dos mesmos índios, e tantos, que só na expedição em que foi o Capitão General João Pedro da Câmara, morreram mais de duzentos"; o trabalho nas plantações de arroz e na construção da fortaleza da vila de Macapá, pois "tem morrido também infinitos, chegando-se até o ponto de se tirarem os rapazes das Escolas, para suprirem aos aterros, e mais serviços daquela Praça". ${ }^{64}$

O alto índice de mortalidade devia-se não só à exaustão no trabalho, mas também ao fato de que os índios empregados nas obras da fundação da vila Nova de Mazagão e da Fortificação de Macapá, comumente recebiam alimentos estragados como ração. Além disso, eram frequentemente desviados das obras públicas pelo comandante e governador da Praça de Macapá para "suas negociações particulares, mandando-os com canoas pelas Povoações dirigidas pelos soldados dos destacamentos a negociarem". ${ }^{65}$

${ }^{62}$ Ofício do governador e capitão-general do Estado do Grão-Pará e Maranhão, Manuel Bernardo de Melo e Castro, para o [secretário de Estado da Marinha e Ultramar], Francisco Xavier de Mendonça Furtado, 26/06/1761, AHU, Pará (Avulsos), Cx. 49, D. 4519.

${ }_{63}$ Ofício do governador e capitão-general do Estado do Grão-Pará e Maranhão, João Pereira Caldas, para o [secretário de Estado da Marinha e Ultramar], Martinho de Melo e Castro, 06/ 06/1773, AHU, Pará (Avulsos), Cx. 71, D. 6024.

${ }^{64}$ Ofício do governador e capitão-general do Estado do Grão-Pará e Maranhão, João Pereira Caldas, para o [secretário de Estado da Marinha e Ultramar], Martinho de Melo e Castro, 07/ 04/1773, AHU, Pará (Avulsos), Cx. 70, D. 5993.

${ }_{65}$ Ofício do intendente-geral do Comércio, Agricultura e manufaturas e juiz conservador da Companhia Geral de Comércio do Grão-Pará e Maranhão, João de Amorim Pereira, para o secretário de Estado dos Negócios do Reino e Mercês, D. Tomás Xavier de Lima Vasconcelos Brito Nogueira, visconde de Vila Nova de Cerveira, 31/12/1777, AHU, Pará (Avulsos), Cx. 78, D. 6508. 
Por sua vez, os índios, ao irem vivenciando tais experiências, foram construindo uma consciência de explorados, percebendo, claramente, que seus interesses eram preteridos em relação aos do Estado, levando-os a desenvolver estratégias de resistência e a fortalecer as redes de solidariedades tecidas no interior das povoações. Evidências desse fato são abundantes na documentação. Os índios que trabalhavam na Casa Forte da Vila de Ourém "aqui murmuram de se não pagar o seu trabalho, de terem servido de bestas de carga". ${ }^{66}$

Apesar de no Regimento do Diretório se repetir à exaustão que os efeitos produzidos por seu trabalho resultariam na melhora substancial das suas condições de vida, os índios logo perceberam a falácia de tal discurso, pois demonstravam "a quase invencível desconfiança [...] de [que] os negócios de suas Povoações, não são para eles, mas sim para S. Maj., procedendo esta má fé de ficar o produto dos seus efeitos empatado na mão do Tesoureiro". ${ }^{67}$

Os índios também demonstravam ter consciência da exploração a que eram submetidos pela Companhia Geral de Comércio do GrãoPará e Maranhão. Aproveitando-se do monopólio comercial que detinham no Estado, os administradores da Companhia pagavam aos índios preços irrisórios pelos gêneros produzidos nas roças do comum e coletados no negócio do sertão. Na tentativa de vender seus produtos diretamente no mercado europeu, os índios das vilas de Faro e Alenquer encaminharam um requerimento ao intendente geral do Comércio, Agricultura e Manufaturas, João Amorim Pereira, que acumulava o cargo de juiz conservador da Companhia, com o seguinte teor:

Pretendendo os índios das Vilas de Faro, e Alenquer embarcar setenta, e quatro arrobas, e vinte e seis arráteis de salsaparrilha, como também quinze barris de óleo de copaíba nos Navios da Companhia, os quais se achavam a carga neste Porto para se desempenharem do empenho em que se acham gravados na Tesouraria Geral, o que mostra o documento

\footnotetext{
${ }^{66}$ Ofício de Luís Bertini Conrat, comandante da Casa Forte a Vila de Ourém, 03/07/1759, APEP, Códice 95: Correspondência de Diversos com o Governo. Ano de 1759, Doc. 82, p. 244.

${ }^{67}$ Ofício do governador e capitão-general do Estado do Grão-Pará e Maranhão, Manuel Bernardo de Melo e Castro, para o [capitão-general], Francisco Xavier de Mendonça Furtado, 09/ 08/1759, AHU, Pará (Avulsos), Cx. 45, D. 4106.
} 
n. 2 em razão de terem aqueles gêneros maior reputação na Cidade de Lisboa do que nesta, onde os paga a mesma Companhia por um preço muito diminuto a proporção do que alcança naquela Cidade. ${ }^{68}$

Claro que os administradores da Companhia, vale ressaltar, com o apoio do governador do Estado, embargaram tal pretensão, extremamente perigosa aos seus interesses, alegando que "os índios se não regulam pelas Leis que são comuns a todos, e que tem outras particulares que em muitas coisas como nesta os fazem diferentes querendo fazer comum o comércio de todos os índios universalmente, e diferente dos demais Moradores Brancos". 69

A remuneração destinada aos índios por seu trabalho era considerada por eles com mais um indício da exploração a que eram submetidos, o que levava muitos deles a tentar persuadir os outros "a não trabalharem, pois seriam enganados com duas varas de pano em casa do Tesoureiro". ${ }^{70}$ Por esse motivo, ao assumir o governo do estado do GrãoPará e Maranhão, João Pereira Caldas, considerando insignificante o valor do salário pago aos índios "ocupados no Real serviço, e no dos particulares", que era de quatrocentos réis por mês, baixou um bando em que fixava salários de acordo com o tipo de serviço, a faixa etária e o sexo. ${ }^{71}$

Procurando contornar a forte rejeição dos índios ao trabalho na construção da Fortaleza de Macapá, ficou estabelecido que o salário

\footnotetext{
${ }^{68}$ Ofício do intendente-geral do Comércio, Agricultura e manufaturas e juiz conservador da Companhia Geral de Comércio do Grão-Pará e Maranhão, João de Amorim Pereira, para o secretário de Estado dos Negócios do Reino e Mercês, D. Tomás Xavier de Lima Vasconcelos Brito Nogueira, visconde de Vila Nova de Cerveira, 31/12/1777, AHU, Pará (Avulsos), Cx. 78, D. 6508 .

${ }^{69}$ Ofício do intendente-geral do Comércio, Agricultura e Manufaturas e juiz conservador da Companhia Geral de Comércio do Grão-Pará e Maranhão, João de Amorim Pereira, para o secretário de Estado dos Negócios do Reino e Mercês, D. Tomás Xavier de Lima Vasconcelos Brito Nogueira, visconde de Vila Nova de Cerveira, 31/12/1777, AHU, Pará (Avulsos), Cx. 78, D. 6508 .

${ }^{70}$ Ofício do diretor da Vila de Souzel, Cosme Damião da Silva, para o governador e capitãogeneral do Estado do Grão-Pará e Maranhão, Manuel Bernardo de Melo e Castro, 28/06/ 1761, APEP, Códice 106: Correspondência de Diversos com o Governo. Ano de 1761, Doc. 84 , p. 206.

71 Ofício do governador e capitão-general do Estado do Grão-Pará e Maranhão, João Pereira Caldas, para o [secretário de Estado da Marinha e Ultramar], Martinho de Melo e Castro, 29/ 07/1773, AHU, Pará (Avulsos), Cx. 71, D. 6032.
} 
dos que lá trabalhassem seria de $1 \$ 200$ réis por mês, "e nesta conformidade não só o ficarão vencendo em todo o Real serviço, mas ainda quando concedidos por Portarias aos particulares". O mesmo salário seria recebido pelos índios empregados em serviços pesados, "como o de Roças, Engenhos, Cortes de Madeiras, transportes das mesmas, e pedras; ou em Navegações igualmente pesadas", e no negócio do sertão. Aos que fizessem serviços domésticos, como "Pescadores, e Caçadores", o salário arbitrado seria de oitocentos réis por mês e aos jovens até treze anos, o de seiscentos réis mensais. ${ }^{72}$

Dentro da mais perfeita lógica do capitalismo ou, se quisermos, da sociedade cristã ocidental, às trabalhadoras índias que faziam os mesmos serviços foram arbitrados salários menores.

[As que fizerem] serviços pesados de Roças, fazer farinhas, e em Amas de leite vençam também oitocentos réis por mês. Que as outras índias empregadas em serviços domésticos, e leves, vençam a seiscentos reis por mês Que as índias raparigas, até a idade de doze anos, vençam a quatrocentos reis por mês. ${ }^{73}$

No bando, o governador deixava claro que os salários não seriam pagos em dinheiro, mas em gêneros, "além do ordinário, e preciso sustento com que se costuma contribuir aos mesmos índios". ${ }^{74}$

\section{Trabalho, epidemias e resistência indígena}

Os esforços do governador não surtiram muito efeito, já que os índios continuavam a fugir dos serviços como o diabo foge da cruz. Ao primeiro sinal de que seriam convocados para o trabalho, os índios "escondem-se sendo todo o seu intento o fugirem de todo o serviço". 75

\footnotetext{
${ }^{72}$ Bando dado nesta Cidade de Belém pelo governador e capitão-general João Pereira Caldas, aos trinta dias do mês de Maio do Ano do Nascimento de Nosso Senhor Jesus Cristo de mil setecentos setenta e três. Anexo do Ofício do governador e capitão-general do Estado do Pará e Rio Negro, João Pereira Caldas, para o secretário de Estado da Marinha e Ultramar, Martinho de Melo e Castro, 29/07/1773, AHU, Pará (Avulsos), Cx. 71, D. 6032.

${ }^{73}$ Bando dado nesta cidade de Belém, AHU, Pará (Avulsos), Cx. 71, D. 6032.

${ }_{74}$ Bando dado nesta cidade de Belém, AHU, Pará (Avulsos), Cx. 71, D. 6032.

75 Auto da Devassa tirada na Vila de Portel, 15/04/1768, APEP, Códice 160: Devassas. 17651769, Doc. s/n.
} 
Alguns Principais mantinham os índios informados de quando seriam requisitados para prestar serviços,

pois, quando o Diretor nomeia algum para o serviço, o mesmo, ao saber, procura logo fugir, e ainda quando desertam do serviço de El Rey procuram refúgio na roça do dito Principal, o qual ali os conserva dois e três meses, e todo o tempo que os mesmos fugidos querem. ${ }^{76}$

Quando os diretores, para atender a solicitação de moradores munidos de portarias do governador, mandavam buscar índios em suas roças era comum "acharem a estes já fugidos por o mesmo Principal os ter mandado antes avisar que se retirem porque os vão buscar para o serviço". ${ }^{77}$ Essa rede de cumplicidade tecida entre os Principais e os índios não excluía conflitos, que, muitas vezes, no cotidiano das povoações, explodiam em ações de violência. ${ }^{78}$

Como já dito antes, embora fosse o mais comum, as fugas não eram o único recurso utilizado pelos índios para se eximirem do trabalho. Alguns buscavam a via institucional, como fez um índio da vila de Bragança, que apresentou ao diretor um despacho do governador, que the autorizava a "eximir-se do serviço, e andar vadio, com outros viandantes". ${ }^{79}$ A crescente exigência de trabalhadores para as obras públicas, aliada à constante dificuldade de obter índios, fazia com que se recorresse a escravos de aluguel, "escravos de particulares, e da Câmara desta Cidade, porque se pagão pela Real Fazenda a cento, e quarenta réis". ${ }^{80}$

Além do aluguel de escravos, as autoridades coloniais buscavam alternativas de obtenção de mão de obra indígena para os "serviços Reais", como, por exemplo, a retirada de índios de

${ }^{76}$ Auto da Devassa tirada na Vila de Souzel, 25/10/1768, APEP, Códice 160: Devassas. 17651769, Doc. s/n.

77 Auto da Devassa tirada na Vila de Veiros, 29/12/1766, APEP, Códice 160: Devassas. 17651769 , Doc. s/n.

${ }^{78}$ Sobre a violência nas relações entre principais, autoridades indígenas e índios nas povoações do Diretório ver: José Alves de Souza Junior, "O cotidiano das povoações no Diretório", Revista de Estudos Amazônicos, v. V, n. 1 (2010), pp. 79-106.

79 Ofício do diretor da Vila de Bragança, Thomas José de Lima, para o governador e capitão-general do Estado do Grão-Pará e Maranhão, Manuel Bernardo de Melo e Castro, 28/05/1761, APEP, Códice 106: Correspondência de Diversos com o Governo. Ano de 1761, Doc. 57, p. 150.

${ }^{80}$ Ofício do governador e capitão-general do Estado do Grão-Pará e Maranhão, João Pereira Caldas, para o [secretário de Estado da Marinha e Ultramar], Martinho de Melo e Castro, 07/ 04/1773, AHU, Pará (Avulsos), Cx. 70, D. 5993. 
outro serviço em que andam ocupados, como sucedeu, quando o sargento mor João de Souza foi para o Mato Grosso levar as cartas ao Sr. Antônio Rolim, que não tendo [a vila de] Serpa, nem [a de] Borba índios, que o remassem, os mandou o Governador do Rio Negro tirar do negócio do sertão, para aquela precisa diligência. ${ }^{81}$

Também era feito o deslocamento de índios de áreas bem distantes de onde iam trabalhar. Este foi o caso de 57 índios trazidos da capitania do Maranhão para prestar serviço nas obras do Arsenal em Belém. ${ }^{82}$

As fugas não significavam, necessariamente, a rejeição dos índios a viverem nas povoações e a se integrarem no convívio dos brancos. Muitos deles perceberam as utilidades que podiam tirar desse convívio, como o acesso a ferramentas mais eficientes para o cultivo de suas roças, a garantia, apesar das dificuldades, do alimento diário, a proteção das autoridades coloniais em relação às rivalidades intertribais. Por isso, embora tenham ocorrido fugas definitivas e proliferação de mocambos no Estado, indicadores de que seus protagonistas não pretendiam retornar às povoações, e índios que tentassem mudar de patrões, como os que fugiram "para as Povoações Francesas", ${ }^{83}$ os fugitivos ou voltavam à povoação, após ter passado a situação que não os satisfazia, ou transitavam entre elas. Alguns exemplos permitem corroborar essas afirmações.

Dez índios fugiram da vila de Oeiras e se refugiaram "pelas roças dos moradores da Vila de Melgaço, alguns com suas famílias". ${ }^{84}$ Houve situações em que o diretor da povoação na qual os desertores buscaram refúgio se negou a devolvê-los, como demonstra a solicitação do diretor do lugar de Mondim, Manoel Francisco Gonçalves, ao governador para

${ }^{81}$ Ofício do governador e capitão-general do Estado do Grão-Pará e Maranhão, João Pereira Caldas, AHU, Pará (Avulsos), Cx. 70, D. 5993.

82 Ofício do governador e capitão-general do Estado do Grão-Pará e Maranhão, Manuel Bernardo de Melo e Castro, para o secretário de Estado da Marinha e Ultramar, Francisco Xavier de Mendonça Furtado, 19/10/1761, AHU, Pará (Avulsos), Cx. 51, D. 4643.

83 Ofício do governador e capitão-general do Estado do Grão-Pará e Maranhão, D. Francisco de Souza Coutinho, para o comandante e diretor da Vila de Macapá, Lourenço de Almeida, 22/ 06/1793, APEP, Códice 83: Correspondência de Diversos com o Governo. 1754-1799, doc. 59, p. 150.

${ }^{84}$ Ofício do diretor da Vila de Oeiras, Tomás Antônio Rebello Cunha, para o governador e capitão-general do Estado do Grão-Pará e Maranhão, Manuel Bernardo de Melo e Castro, 13/ 05/1759, APEP, Códice 95: Correspondência de Diversos com o Governo. Ano de 1759, doc. 44, p. 127. 
que "fosse servido mandar uma Portaria para que o Diretor, e juntamente o Principal da Vila de Chaves entregassem os índios e índias que se acham fugidos na dita Vila, e pelas roças dos moradores da dita Vila". ${ }^{85}$

Havia, também, índios que fugiam de uma vila para outra para se unir a parentes próximos. Este foi o caso de quatro índias que fugiram da vila de Faro, levando seus filhos, para a de Óbidos, "onde se achavam com um parente muito chegado, chamado Domingos, com quem já estiveram em um mocambo" ${ }^{86}$ Em outra ocasião, na mesma vila de Faro, "acha-se ainda bastante gente fugida no mato, há notícias que estão ao redor da Povoação, e que a ela vão a cada passo falar aos parentes". ${ }^{87}$ Por duas vezes, os sete índios requisitados pelo bispo d. Miguel de Bulhões, na qualidade de governador interino do Estado, para o serviço Real "desampararam os cabos que os levavam e aparecendo nesta Vila depois de algum tempo". ${ }^{88}$

Além das deserções, outro fator que também contribuiu para o colapso demográfico das povoações foram as altas taxas de mortalidade causadas por epidemias trazidas pelos europeus e, principalmente, por navios negreiros que aportavam em Belém. Como mostram Alden e Miller, as epidemias grassaram nos mesmos períodos, tanto no estado do Maranhão e Pará como no Estado do Brasil, e foram coincidentes com crises de fome provocadas pela seca na África ${ }^{89}$ Tal situação reforça a tese que relaciona o tráfico de escravos com os surtos epidêmicos. ${ }^{90}$

${ }^{85}$ Ofício do diretor do Lugar de Mondim, Manoel Francisco Gonçalves, para o governador e capitão-general do Estado do Grão-Pará e Maranhão, Manuel Bernardo de Melo e Castro, 14/05/1759, APEP, Códice 95: Correspondência de Diversos com o Governo. Ano de 17591, doc. 45, p. 153.

${ }^{86}$ Ofício do diretor da Vila de Faro, Constantino (sobrenome ilegível), para o governador e capitãogeneral do Estado do Grão-Pará e Maranhão, Manuel Bernardo de Melo e Castro, 08/06/1761, APEP, Códice 106: Correspondência de Diversos com o Governo. Ano de 1761, doc. 62, p. 161.

${ }^{87}$ Auto da Devassa tirada na Vila de Faro, 17/01/1770, APEP, Códice 160: Devassas. 17651769 , Doc. s/n.

${ }^{88}$ Ofício do diretor da Villa de Souzel, Cosme Damião da Silva, para o governador e capitãogeneral do Estado do Grão-Pará e Maranhão, Manuel Bernardo de Melo e Castro, 31/06/1759, APEP, Códice 95: Correspondência de Diversos com o Governo. Ano de 1759, doc. 77, p. 224.

89 Dauril Alden e Joseph Miller, "Out of Africa: The Slave Trade and the Transmission of Smallpox to Brazil”, Journal of Interdisciplinary History, v. 18, n. 2 (1987), pp. 195-224, 202-04, 218-20.

${ }^{90}$ David Noble Cook e Willian George Lovell, "Unravelling the Web of Disease", in Cook, Lovell (orgs.), Secret Judgments of God: Old World Disease in Colonial Spanish America (Normam: The University of Oklahoma Press, 1992), pp. 213-42, 218-19; Philip Curtin, "Epidemiology and the Slave Trade", Political Science Quartely, v. 83, n. 2 (1968), pp. 190-216; Magali Romero Sá, 
Alencastro considera que a expansão ultramarina promoveu a "união microbiana do mundo". Afirma também que o grande impacto causado pelas epidemias euroafricanas sobre as populações indígenas da América do Sul pode ser explicado "pela menor capacidade de resistência à invasão de células patogênicas", decorrente "da reduzida diversidade genética" dos índios da região. ${ }^{91}$

À medida que as populações indígenas sofriam o choque epidêmico provocado pela conquista, as possibilidades de utilização da mão de obra indígena pelos colonos iam sendo reduzidas, o que, em contrapartida, estimulava a intensificação do tráfico de escravos. ${ }^{92}$ Os resultados catastróficos das epidemias sobre os índios foram evidentes. A epidemia da "grande varíola", acompanhada de disenteria, que assolou Belém, São Luís e o interior do estado, em 1749, ficou conhecida com essa denominação, devido à imensa destruição que causou entre os índios, sendo os mais afetados os que haviam sido recém-descidos do rio Branco. Segundo o relato de um contemporâneo, Manuel Ferreira Leonardo, a quantidade de mortos era tanta que os cemitérios dos conventos não deram conta de enterrar todos os corpos, por isso muitos foram enterrados em campo aberto. ${ }^{93}$

O governador Francisco Pedro de Mendonça Gurjão, ao informar as consequências demográficas do surto epidêmico de 1749 à corte, escrevia: aldeias inteiras ficaram vazias "pelo grande número de Índios, e mestiços que deveram o contágio que ali se contaminou [...], como as fazendas dos moradores pelo grande número de escravos que tinham falecido". Ao ordenar aos oficiais militares a contagem dos

“A 'peste branca' nos navios negreiros: epidemias de varíola na Amazônia colonial e os primeiros esforços de imunização", Revista Latinoamericana de Psicopatologia Fundamental, v. 11, n. 4, supl. (2008), pp. 818-26.

91 Luiz Felipe de Alencastro, O trato dos viventes: formação do Brasil no Atlântico Sul, São Paulo: Companhia das Letras, 2000, p. 127. Alencastro fornece uma relação das enfermidades disseminadas por europeus e africanos na América. Deve-se aos primeiros a introdução da varíola, rubéola, escarlatina, tuberculose, lepra, doenças venéreas e dermatoses; já os segundos trouxeram para o Novo Mundo o tracoma, a dracunculose, o amarelão, a febre amarela, a malária, p. 128. Essa tese também é defendida por Domingues, Quando os índios eram vassalos, p. 180.

92 Alencastro, O trato dos viventes, p. 127; Domingues, Quando os índios eram vassalos, p. 54.

93 Hemming, Ouro vermelho, p. 651; Domingues, Quando os índios eram vassalos, pp. 180-1. 
mortos em Belém, o número obtido foi de 4.900, considerado por Gurjão incompatível com o número de moradores da cidade. Por esse motivo, pretendia o governador verificar a mortandade provocada pela epidemia em toda a capitania do Pará e regiões adjacentes. ${ }^{94}$ No entanto, o Conselho Ultramarino apresentou várias listas de mortos e, em duas delas, os números apontados eram de 3.348, incluindo as fazendas dos jesuítas, e de 3.061, só para a freguesia da Campina, em Belém. ${ }^{95}$

No ano de 1750, novo surto de bexigas (varíola) atingiu o Pará, "provenientes de alguns navios negreiros ali aportados, e suas consequências [foram] nefastas junto à mão de obra". ${ }^{96}$ Os números informados pelo governador Gurjão em carta a d. João V sobre a mortandade provocada pela nova manifestação da varíola na capitania teriam sido colocados em dúvida, pois informou ao reino que: "consta-me que houve quem com sinistras informações, movido só das conveniências particulares, quis capacitar a V. Maj. de que o contágio não tinha sido com aquela veemência". Isto o levou a ordenar que fosse feito um levantamento do número de índios e mestiços mortos, com base nas listas de aldeias, que apresentou só para as fazendas dos religiosos de Belém o número de 10.777 mortos. Acrescentava ainda que:

junto com sete mil e seiscentos dos moradores da mesma Cidade importam dezoito mil trezentos e setenta e sete como consta no resumo junto, não entrando as inumeráveis fazendas desta Capitania, nem as Vilas da Vigia, Caeté, e Cametá, e as mais pessoas que andam dispersas pelo Sertão, que fazendo uma proporcionada conta, ou orçamento a todos hão de chegar a quarenta mil. ${ }^{97}$

\footnotetext{
${ }_{94}$ Carta do governador e capitão-general do Estado do Maranhão e Pará, Francisco Pedro de Mendonça Gurjão, para o rei D. João V, 26/04/1749. Anexo à Consulta do Conselho Ultramarino para o rei D. João V, sobre a carta do governador e capitão-general do Estado do Maranhão e Pará, Francisco Pedro de Mendonça Gurjão. AHU, Pará (Avulsos), Cx. 31, D. 2976.

95 Conselho Ultramarino, Consulta da Carta à Governador Francisco Pedro de Mendonça Gorjão, 16/05/1750, AHU, Pará (Avulsos), Cx. 31, D. 2976. Chambouleyron, Barbosa, Bombardi e Sousa também trabalham esses dados em “'Formidável contágio": epidemias, trabalho e recrutamento na Amazônia colonial (1660-1750)", História, Ciências, Saúde - Manguinhos, v. 18, n. 4 (2011), p. 992.

${ }^{96}$ Carta do governador e capitão-general do Estado do Maranhão e Pará, Francisco Pedro de Mendonça Gurjão, para o rei D. João V, 13/08/1750, AHU, Pará (Avulsos), Cx. 31, D. 2982.

${ }_{97}$ Carta do governador, 13/08/1750, AHU, Pará (Avulsos), Cx. 31, D. 2982.
} 
Os números alarmantes apresentados pelo governador, apesar de colocados em dúvida, permitem confirmar os efeitos devastadores das epidemias na população indígena, hipótese que também é válida para toda a Colônia. ${ }^{98} \mathrm{Tal}$ fato levou os colonos a reduzirem sua resistência à utilização de escravos africanos. Ao impacto crescente das epidemias sobre os índios correspondia uma maior pressão sobre a mão de obra indígena, materializada na insistência dos colonos em realizar novos descimentos. Parece não haver dúvida de que a redução demográfica dos aldeamentos, que diminuía o número de trabalhadores nas propriedades, estava indissociavelmente ligada à intensificação do apresamento. ${ }^{99}$

O esvaziamento das povoações causado pelas fugas e pelos surtos epidêmicos foi intensificado durante a vigência do Diretório. Isto pode ser demonstrado pelo fato de que, nos seus últimos anos, poucas povoações preenchiam o número mínimo de população estabelecido no seu Regimento, e que era de 150 índios.

No ano de 1774 , das 54 povoações existentes na capitania do Pará, apenas seis excediam o piso populacional: Portel, com 512 índios, Monte Alegre, com 247, Vila Franca, com 201, Melgaço, com 181, Oeiras, com 159 e Pombal, com 158. Outras seis apresentavam populações entre 100 e 150 índios: Veiros, com 139, Santarém, com 122, Monforte, com 121, Souzel, com 110, Chaves com 109 e Cintra, com 107. As 41 povoações restantes tinham em média uma população de 50 índios, havendo algumas, como o lugar de Villar, com apenas 11 índios. ${ }^{100}$ Embora se referissem aos relatórios das missões, as observações de Hemming servem para descrever a situação demográfica das povoações nos últimos anos do Diretório: "elas se tornavam verdadeiras babéis,

98 Dauril Alden também comenta os efeitos catastróficos das epidemias nas populações indígenas em "El Indio desechable em El Estado de Maranhão durante los siglos XVII e XVIII", America Indigena, v. XLV, n. 2 (1985), p. 437.

99 John Manuel Monteiro, Negros da terra. Índios e bandeirantes nas origens de São Paulo. São Paulo: Companhia das Letras, 1994, p. 157.

${ }^{100}$ Mapa dos Oficiais, e mais índios das Povoações da Capitania do Grão Pará, capazes de serviço, e da distribuição em que existiam no fim de Junho de 1774. Anexo ao Ofício do governador e capitão-general do Estado do Pará e Rio Negro, João Pereira Caldas, para o secretário de Estado da Marinha e Ultramar, Martinho de Melo e Castro, 12/04/1775, AHU, Pará (Avulsos), Cx. 74, D. 6212. 
povoadas por remanescentes de muitas tribos diferentes, vindas de lugares distantes da Amazônia". ${ }^{101}$

Tal situação tinha reflexos profundamente negativos na economia do Estado, o que pode ser constatado pela análise de sua balança de exportações durante a vigência do Diretório dos Índios. Entre 1756 e 1777, a quantidade de arrobas de cacau produzido e/ou coletado, um dos principais produtos de exportação do estado, tendeu a cair vertiginosamente. Se trabalharmos apenas os dados referentes à exportação do cacau feita somente pelos lavradores, podemos constatar que no ano de 1757, o primeiro do Diretório, foram exportadas 33.115@28 libras, enquanto no ano de 1769, o volume de exportação caiu para 10@. No período de 1758 a 1777, a quantidade de cacau exportada pelos lavradores manteve-se abaixo das 10.000@, sendo que no último ano do referido período eles exportaram para o Reino 675@. ${ }^{102}$ Embora o problema da escassez de mão de obra não tenha sido o único motivo da acentuada queda do volume de exportação de cacau, pois diversos outros, como as fortes chuvas, também contribuíram, não se pode negar que o mesmo foi de suma importância para que tal fato sucedesse.

Já em 1750, antes mesmo da implantação do Diretório dos Índios, o governador Francisco Pedro de Mendonça Gurjão chamava a atenção para os prejuízos causados pela redução de mão de obra indígena nas propriedades dos moradores, que afetaram as

culturas daquele Estado, cujo resultado teria sido uma fome considerável de farinhas, chegando a custar o alqueire a mil e quinhentos réis, quando seu preço ordinário era de Cruzado até cinco tostões em cacau, e a esta proporção todos os mais viveres se reduziram a maior carestia. $^{103}$

\footnotetext{
${ }^{101}$ Hemming, Ouro vermelho, p. 650.

${ }^{102}$ Mapa dos diferentes Gêneros que se exportaram do Porto da Cidade do Pará desde o ano de 1756 até o de 1777 inclusive, em que no espaço de todos existiu a Companhia Geral do Comércio. Preços, que em cada um dos mesmos anos tiveram. Embarcações em que se navegarão. Nomes dos Comandantes, e Capitães delas. Valor da exportação em cada ano. A importância total em todos eles. Anexo ao Ofício do governador e capitão-general do Estado do Pará e Rio Negro, João Pereira Caldas, para o secretário de Estado da Marinha e Ultramar, Martinho de Melo e Castro, 31/08/1778, AHU, Pará (Avulsos), Cx. 80, D. 6627.

${ }^{103}$ Carta do governador, 13/08/1750, AHU, Pará (Avulsos), Cx. 31, D. 2982.
} 


\section{Da necessidade de lhes mandarem tapanhunos de Angola e Guiné, para de todo não se perderem as fazendas}

O apelo dos oficiais da Câmara de São Luís à Corte, em $1665,{ }^{104}$ continuou ressoando na segunda metade do século XVIII entre os moradores e autoridades coloniais do estado do Grão-Pará e Maranhão. Ainda nos Seiscentos, o governo português tentou estimular o tráfico negreiro para o Norte, por meio de isenções tributárias. Estes foram os casos das Provisões Régias de 18 de março de 1662, que livrava da metade dos direitos os negros de Angola que fossem introduzidos no estado do Maranhão, e de $1^{\circ}$ de abril de 1680, que determinava o envio, todos os anos, de negros da costa da Guiné para o Maranhão e Pará por conta da Fazenda Real. Com essas medidas, a Coroa procurava reduzir o preço do escravo africano na região e tornar tal alternativa de mão de obra atraente aos moradores, levando-os a abandonar a utilização e o tráfico de escravos vermelhos. ${ }^{105}$

No estudo sobre o comércio de escravos para o Maranhão, Silva aponta para três períodos desse comércio, por ele considerados bem definidos: o primeiro de 1680 a 1755 , em que as capitanias do Norte recebiam escravos de mercadores privados, dispostos a investir no comércio de escravos, ${ }^{106}$ e de duas companhias de comércio, a Companhia de Estanco do Maranhão e a Companhia de Cacheu e Cabo Verde; o segundo de 1756 a 1777, dominado pelo monopólio da Companhia Geral de Comércio do Grão-Pará e Maranhão (CGPM); e o terceiro de 1778 a 1846, ano do último registro de desembarque de escravos no Maranhão. ${ }^{107}$

As reformas pombalinas criaram um novo contexto para o tráfico de escravos. Com o objetivo de liberar o comércio de escravos, foram

\footnotetext{
${ }^{104}$ Carta ao rei dos oficiais da Câmara de São Luís, 22/08/1665, AHU, Maranhão (Avulsos), Cx. 4, D. 499.

${ }^{105}$ Provisões de 18 de março de 1662 e de $1^{\circ}$ de abril de 1680, APEP, Diversos, 1655-1778, doc. $\mathrm{s} / \mathrm{n}$.

${ }^{106}$ Carreira apresenta um levantamento de inúmeros contratos de assento ou de "licenças para navegar escravos", efetuados a partir dos últimos anos do século XV até meados do XVII. Antônio Carreira, "As companhias pombalinas de navegação, comércio e tráfico de escravos entre a costa africana e o nordeste brasileiro", Boletim Cultural da Guiné Portuguesa, XIV, v. XXII, n. 089 e 090 (1968), p. 13 e sgs.

${ }^{107}$ Daniel B. Domingues da Silva, "The Atlantic Slave Trade to Maranhão, 1680-1846" Volume, Routes and Organization, Slavery and Abolition, v. 29, n. 4 (2008), p. 478.
} 
abolidos o sistema de esquadra (1756) e o sistema de frotas (1765). Além disso, uma reforma tributária eliminou ou reduziu diversas taxas. Em 1776, penúltimo ano de vigência do monopólio da companhia, houve a redução dos valores dos fretes cobrados pelos capitães dos navios negreiros, com o objetivo de diminuir os custos dos escravos para os proprietários de terras e estimular as trocas. ${ }^{108}$

No período anterior a CGPM, o fornecimento de escravos para o estado do Maranhão e Pará era feito principalmente pelos portos africanos do Atlântico equatorial, ${ }^{109}$ mais precisamente os portos da Senegâmbia, na costa da Alta Guiné, especialmente Bissau (39,8\%) e Cacheu $(21,9 \%)$. No entanto, o estado também recebia escravos de Serra Leoa, Cabo Verde e de outros portos da costa da Alta Guiné. A Costa da Mina, nesse período, era para os mercadores de escravos portugueses e brasileiros, uma longa linha costeira que se estendia do Cabo Palmas, na fronteira da atual Libéria com a Costa do Marfim, até o Cabo Lopes, no Gabão. ${ }^{110}$

Após o estabelecimento da CGPM, a Senegâmbia continuou a ter grande importância no suprimento de escravos para o estado do GrãoPará e Maranhão, mas houve uma mudança da sua fonte secundária da Costa da Mina para Angola, na África Centro-Ocidental. "Luanda sozinha forneceu cerca de $21,5 \%$ de todos os escravos desembarcados no Maranhão". ${ }^{111}$ No período de 1721 a 1771, "de Luanda, o maior porto negreiro africano do sul do Equador, foram exportados 204 mil escravos, metade dos quais para o Rio de Janeiro". ${ }^{112}$ Contudo, os portos do Atlântico equatorial mantiveram sua supremacia no tráfico de escravos para o Maranhão até meados do século XIX, começando a declinar após as tentativas inglesas de abolição do tráfico de escravos atlântico.

\footnotetext{
${ }^{108}$ Manolo Florentino, Alexandre Vieira Ribeiro, Daniel Domingues da Silva, "Aspectos comparativos do tráfico de escravos para o Brasil (séculos XVIII e XIX)”, Afro-Ásia, n. 31 (2004), pp. 91-2.

${ }^{109}$ Rafael Chambouleyron, "Escravos do Atlântico equatorial: tráfico negreiro para o Estado do Maranhão e Pará (século XVII e início do século XVIII)", Revista Brasileira de História, São Paulo, v. 26, n. 52 (2006), pp. 79-114.

${ }^{110}$ Silva, "The Atlantic Slave Trade", p. 485

${ }^{111}$ Silva, "The Atlantic Slave Trade", p. 486.

${ }^{112}$ Florentino, Ribeiro e Silva, "Aspectos comparativos", p. 89
} 
Em outras palavras, o Maranhão permaneceu integrado a um sistema de tráfico de escravos muito mais similar aos dos portos das ilhas do Caribe e da América do Norte, do que dos portos de outras partes da América portuguesa. ${ }^{113}$

A CGPM, cujos privilégios e esfera de influência foram bastante ampliados pelo Alvará de 28 de novembro de 1757, conhecido como o alvará secreto, enviou para o Pará, em 1758, seis navios, trazendo um carregamento total de 1.670 escravos, oriundos de Bissau, Cacheu e Angola; quatro navios da Guiné, com 680 escravos; e dois de Angola, com 990 escravos. De 1757 a 1777, período de vigência do seu monopólio, a Companhia teria introduzido no Pará, Maranhão e Rio de Janeiro um total de 25.279 escravos e 84 crias. Desse total, segundo os dados de Carreira, o Pará recebeu, entre 1756 e 1774, 21.648 escravos. ${ }^{114}$

Quando as carregações chegavam a Belém, os escravos eram expostos na praça do mercado, com tabuletas penduradas no pescoço que informavam o preço. ${ }^{115}$ A quantidade de pessoas que comparecia aos locais de venda dos carregamentos de escravos era tanta que, segundo o governador, os administradores da Companhia precisavam requisitar ao governo da capitania "alguns soldados para evitarem a confusão de

\footnotetext{
${ }^{113}$ Silva, "The Atlantic Slave Trade", pp. 485-6.

${ }^{114}$ Carreira, "As companhias pombalinas", p. 49. Os números de Carreira diferem, como o próprio autor demonstra em seu trabalho, dos de Cunha Saraiva que, para o mesmo período aponta o número de 19.651 escravos. Já Nunes Dias, indica o número de 25.365 escravos introduzidos pela Companhia, no mesmo período. Manuel Nunes Dias, A Companhia Geral do Grão-Pará e Maranhão (1755-1778); $1^{\circ}$ Volume, Belém: Universidade Federal do Pará, 1970, p. 465. Cardoso afirma, no entanto, que, no período em que funcionou, a Companhia teria introduzido quase 15.000 africanos no território paraense, grande parte dos quais teria sido reexportada para o Mato Grosso, devido à dificuldade dos colonos em adquiri-los por falta de recursos financeiros. A ideia do desvio de escravos para o Mato Grosso, defendida por Cardoso, é equivocada, já que a referida capitania era um importante mercado de escravos para a Companhia. Ciro Flamarion Cardoso, Economia e sociedade em áreas periféricas: Guiana Francesa e Pará (1750-1817), Rio de Janeiro: Editora Graal, 1984. Já Vicente Salles aponta o número de 12.587 escravos introduzidos pela Companhia no estado, também considerando que "muitos passaram para a capitania do Mato Grosso". Vicente Salles, O negro no Pará, sob o regime da escravidão, Rio de Janeiro: Fundação Getúlio Vargas, Serv. de Publicações [e] Univ. Federal do Pará, 1971, p. 32. Salles cita a fonte de onde tirou o número de escravos e a informação de que foram desviados para o Mato Grosso: a obra de Antônio Ladislau Monteiro Baena, militar português que serviu no Pará no século XIX e que escreveu um compêndio sobre as eras da província do Pará. Antônio Ladislau Monteiro Baena, Compêndio das eras da província do Pará, Belém: Universidade Federal do Pará, 1969, p.194.

${ }^{115}$ Dias, A Companhia Geral, p. 461.
} 
tanto Povo". ${ }^{116}$ Ainda, de acordo com o governador, os carregamentos de escravos eram vendidos rapidamente e, na maioria das vezes, à vista, como foi o caso de um lote de 208 escravos, trazido por um navio proveniente do Porto de Bissau, que foi adquirido "em duas horas com dinheiro à vista sendo tanto o concurso e confusão dos moradores que os queriam comprar que me foi preciso mandar uma guarda de soldados para evitar algumas desordens". ${ }^{117}$ Levando-se em consideração os efeitos produzidos pela Lei da Liberdade dos Índios de 1755 e dos surtos epidêmicos sobre a oferta de mão de obra indígena, não é difícil entender a grande necessidade em que estavam os moradores do Pará de trabalhadores escravos.

Essa pode ser a explicação para o fato de que os carregamentos que chegavam ao Grão-Pará serem vendidos rapidamente e para os constantes tumultos provocados pela disputa dos lotes de negros, cuja quantidade estaria aquém da demanda dos moradores, pois "há pessoas tão faltas de servos, que não têm quem lhes faça um recado, e nem com o dinheiro na mão podem conseguir um Escravo, porque o número é tão pouco". ${ }^{118}$

Tais tumultos parecem ter sido um fato recorrente, já que, segundo o governador Melo e Castro, em "todas as ocasiões em que neste Porto chegam Navios com que a Companhia geral do comércio conduz Pretos para este Estado, são em todos nos excessivos os alvoroços". As queixas constantemente repetidas pelos referidos moradores era a reduzida quantidade de escravos nos lotes trazidos pela companhia, "que apenas chega qualquer destes Navios, que nunca trazem duzentos Pretos, logo são tantos os necessitados, que para se evitar a confusão que

\footnotetext{
${ }^{116}$ Ofício do governador e capitão-general do Estado do Grão-Pará e Maranhão, Manuel Bernardo de Melo e Castro, para o secretário de Estado da Marinha e Ultramar, Francisco Xavier de Mendonça Furtado, 23/01/1760, APEP, Códice No 696: Correspondência do Governo com a Metrópole, 1759-1761, doc. 315.

${ }^{117}$ Ofício do governador e capitão-general do Estado do Grão-Pará e Maranhão, Manuel Bernardo de Melo e Castro, para o secretário de Estado da Marinha e Ultramar, Francisco Xavier de Mendonça Furtado, 03/09/1760, APEP, Códice No 696: Correspondência do Governo com a Metrópole, 1759-1761, doc. 449.

${ }^{118}$ Ofício do governador e capitão-general do Estado do Grão-Pará e Maranhão, Manuel Bernardo de Melo e Castro, para o secretário de Estado da Marinha e Ultramar, Francisco Xavier de Mendonça Furtado, 28/04/1761, AHU, Pará (Avulsos), Cx. 48, D. 4435.
} 
há na sua venda, se mandam por guardas às portas da Companhia", ${ }^{119} \mathrm{e}$ os altos preços cobrados por eles. ${ }^{120}$

Apesar dos alvoroços promovidos pelos moradores nos momentos de venda dos escravos, a maioria deles não possuía cabedais suficientes para comprar à vista ou até mesmo para comprá-los, sendo tal situação exposta com frequência na documentação. Acrescente-se a isto a escassez de moeda nas capitanias do Norte. Por isso, nelas, a compra de escravos a crédito da Companhia foi uma prática comum e que proporcionou a seus administradores fortes dores de cabeça, pois encontravam grandes dificuldades em receber o que lhes era devido. Tais dificuldades foram tão significativas, que d. José I emitiu o Alvará de 9 de junho de 1761, pelo qual proibia os devedores de venderem os seus escravos sem que eles tivessem sido totalmente pagos. ${ }^{121}$

Em ofício, datado de 21 de agosto de 1797 e encaminhado a d. Rodrigo de Souza Coutinho, o governo do Grão-Pará expôs as dificuldades encontradas pela Companhia para vender escravos no Pará:

o atraso, e pobreza desta Colônia cujos Habitantes ainda quando vinham a pagar os Escravos com a mesma demora que os das outras como recai toda sobre o que os introduz porque não há Negociantes que tomem e paguem logo como naquelas ou parte ou toda a Armação para a revenderem depois, fica muito mais vantajoso ao Dono dela vendê-la nos outros Portos por menor preço do que esperar tanto tempo para se embolsar dos maiores que poderá haver neste, pois que tem ordinariamente de pagar riscos avultados em tempos certos, além dos seguros, fretes e outras despesas de que viria a ficar em desembolso por outro tanto tempo. ${ }^{122}$

Algumas conclusões sobre a situação do comércio de escravos no Pará: primeiro, parece não haver dúvida de que a presença de escravos africanos na capitania intensificou-se a partir do século XVIII, e os censos

\footnotetext{
119 Ofício do governador, 28/04/1761, AHU, Pará (Avulsos), Cx. 48, D. 4435.

${ }^{120}$ Ofélia Pinto e Brian West, "Humans as Cost Objects: $18^{\text {th }}$ Century Portuguese Slave Trading", $13^{\text {th }}$ World Congress of Accounting Historians, Newcastle Upon Tyne, 17-19 de julho 2012, p. 22.

${ }^{121}$ Pinto e West, "Humans as Cost Objects", p. 14.

${ }^{122}$ Ofício do governador e capitão-general do Estado do Grão-Pará, Maranhão e Rio Negro, D. Francisco de Souza Coutinho, para o secretário de Estado da Marinha e Ultramar, D. Rodrigo de Souza Coutinho, 21/08/1797, APEP, Códice 702: Correspondência dos Governadores com a Metrópole, 1797-1799, doc. 89.
} 
posteriores assim o demonstraram, ${ }^{123}$ por conta da ação da Companhia Geral de Comércio do Grão-Pará e Maranhão; segundo, a capitania não se constituía no melhor mercado para a venda de escravos, devido ao desenvolvimento incipiente do sistema de plantation, o que justificaria a preferência de seus administradores de vender os carregamentos de escravos em outras áreas que estavam no raio de ação da Companhia, como Mato Grosso, onde eram pagos à vista e com ouro; terceiro, tal preferência pode explicar as disputas pelos moradores dos lotes de escravos que chegavam ao GrãoPará e que, possivelmente, não eram suficientes para todos; quarto, havia na capitania uma elite de negociantes que praticava o açambarcamento dos produtos que eram introduzidos pela companhia de comércio, inclusive escravos, a ponto de haver carregamentos de escravos vendidos antes do desembarque, ${ }^{124}$ quinto, os moradores, apesar das dificuldades, nunca desistiram de utilizar o trabalho indígena, que coexistiu com o dos africanos nas lavouras e nos serviços públicos ainda por muito tempo.

Em setembro de 1765, 346 trabalhadores estavam sendo utilizados em diferentes serviços relacionados à construção da Fortaleza de Macapá, sendo 177 negros e 169 índios. ${ }^{125}$ Assim como os índios, os africanos também resistiam à disciplina de tempo e de trabalho que lhes era imposta. Foi uma constante a fuga de negros escravos que trabalhavam nas obras de construção da Fortaleza de São José de Macapá, cedidos que foram pelo Senado da Câmara de Belém, num total de 174. Em ofício de 19 de fevereiro de $1765,{ }^{126}$ Nuno da Cunha de Ataíde Varona, comandante da Praça de Macapá, informava a fuga de quatro escravos;

\footnotetext{
${ }^{123}$ Capitania do Grão-Pará - Freguesia da Sé desta Cidade. Mapa de todas as Famílias existentes na sobredita Freguesia na qualidade de Lavouras e Serviços, e da quantidade de Efeitos que nela se fizeram e colheram em todo o ano de 1785. Conselho Estadual de Cultura, documentação avulsa. Arquivo do Rio Negro - 1788 - Recenseamento Geral do Grão-Pará, no ano de 1788. Volume II, folhas de 159 a 298. Universidade do Amazonas.

124 Ofício dos oficiais da Câmara da vila de Nossa Senhora de Nazaré da Vigia, para o secretário de Estado da Marinha e Ultramar, Francisco Xavier de Mendonça Furtado, 10/11/1763, AHU, Pará (Avulsos), Cx. 55, D. 5006.

${ }^{125}$ Mapa do $\mathrm{N}^{\mathrm{o}}$ dos Índios e Pretos trabalhadores que a 3 de Setembro do presente ano de 1765 se acham empregados em diferentes destinos respectivos a obra da Fortificação, APEP, Códice $\mathrm{N}^{\mathrm{o}}$ 61: Correspondência de Diversos com os Governadores, Ano de 1765, doc. 38.

${ }^{126}$ Ofício do comandante da Praça de Macapá, Nuno da Cunha de Ataíde Varona, para o governador e capitão-general do Estado do Grão-Pará e Maranhão, Fernando da Costa de Ataíde Teive de Souza Coutinho, 19/02/1765, APEP, Códice No 58: Correspondência de Diversos com os Governadores, Ano 1765, doc. s/n.
} 
em 26 do mesmo mês, os fugitivos já atingiam o número de $17 ;{ }^{127} \mathrm{em}$ agosto daquele ano, o total de negros ausentes das obras da fortaleza chegava a $51 .{ }^{128}$ Segundo o referido comandante, o principal motivo das fugas era "a aspereza com que [...] são aqui tratados os pretos do Senado da Câmara, que concorre para a sua fuga". ${ }^{129}$

Era frequente a presença, nos grupos de fugitivos, de escravos dos proprietários locais, sendo que o maior temor das autoridades era que esses escravos atravessassem a fronteira e entrassem em contato com os negros da Guiana Francesa. Além do envio de tropas para recapturá-los, outras medidas foram tomadas para coibir a fuga, tais como a aplicação de castigos corporais em escravos considerados líderes, ${ }^{130}$ estabelecimento de rondas noturnas para evitar o livre trânsito dos escravos pelas ruas, vigilância permanente sobre os escravos, "tanto nas horas de trabalho, como nas do descanso, não lhes permitindo nestas saírem do distrito da Casa de seu alojamento". ${ }^{131}$

A proximidade do Amapá com a Guiana Francesa causava sérias preocupações às autoridades portuguesas, tanto locais, como metropolitanas. Era recorrente na Vila de Macapá a ideia "de que mais dia menos dia ela há de ser surpreendida pelos Pretos ou pelos Franceses"132,

${ }^{127}$ Ofício do comandante da Praça de Macapá, Nuno da Cunha de Ataide Varona, para o governador e capitão-general do Estado do Grão-Pará e Maranhão, Fernando da Costa de Ataíde Teive de Souza Coutinho, 26/02/1765, APEP, Códice $N^{\circ} 58$ : Correspondência de Diversos com os Governadores, Ano 1765, doc. 36.

${ }^{128}$ Ofício do comandante da Praça de Macapá, Nuno da Cunha de Ataíde Varona, para o governador e capitão-general do Estado do Grão-Pará e Maranhão, Fernando da Costa de Ataíde Teive de Souza Coutinho, 03/08/1765, APEP, Códice N ${ }^{\circ}$ 61: Correspondência de Diversos com os Governadores, Ano 1765, doc. 14.

${ }^{129}$ Ofício do comandante da Praça de Macapá, Nuno da Cunha de Ataíde Varona, para o governador e capitão-general do Estado do Grão-Pará e Maranhão, Fernando da Costa de Ataíde Teive de Souza Coutinho, 20/01/1765, APEP, Códice No 76 : Correspondência de Diversos com os Governadores, Ano 1765, doc. 14.

${ }^{130}$ Ofício do comandante da Praça de Macapá, Nuno da Cunha de Ataíde Varona, para o governador e capitão-general do Estado do Grão-Pará e Maranhão, Fernando da Costa de Ataíde Teive de Souza Coutinho, 16/09/1765, APEP, Códice No 61: Correspondência de Diversos com os Governadores, doc. 44.

${ }^{131}$ Ofício do comandante da Praça de Macapá, Nuno da Cunha de Ataíde Varona, para o governador e capitão-general do Estado do Grão-Pará e Maranhão, Fernando da Costa de Ataíde Teive de Souza Coutinho, 26/02/1765, APEP, Códice No 58: Correspondência de Diversos com os Governadores, Ano 1765, doc. 36.

132 Ofício do comandante da Praça de Macapá, para o governador e capitão-general do Estado do Grão-Pará e Rio Negro, João Nápoles Tello de Menezes, 29/07/1780, APEP, Códice 201: Correspondência de Diversos com os Governadores, Ano de 1780, doc. 15. 
tendo essa ideia sido reforçada por inúmeros acontecimentos ocorridos na vila. Alguns negros, na noite de 28 de dezembro de 1790, armaram uma emboscada e tentaram massacrar o morador João de Souza Machado; ${ }^{133}$ no dia $1^{\circ}$ de setembro de 1791 , um bando de sete negros armados, proveniente de um mocambo localizado nas cabeceiras do rio Araguari, entrou durante a noite na Vila de Macapá e conseguiu convencer dezoito escravos a fugirem com ele. ${ }^{134}$

A documentação indica que a possibilidade de uma invasão francesa no estado do Grão-Pará e Maranhão parece ter sido levada bastante a sério pelo governo metropolitano, pois, em carta datada de 26 de maio de 1756, a Secretaria de Estado da Marinha e Ultramar advertia o Bispo do Pará, dom frei Miguel de Bulhões, que na ocasião exercia interinamente o governo do estado, já que Mendonça Furtado se encontrava na expedição demarcatória dos limites do Tratado de Madri no Rio Negro, "sobre o projeto dos franceses da Guiana de conquistar este Estado". ${ }^{135}$

Os negros amocambados no Amapá mantinham um estreito contato com os franceses da Guiana, para quem vendiam a produção de suas roças, de suas olarias, além de trabalharem como assalariados na construção de suas fortificações. No interrogatório a que foi submetido, o preto Miguel, escravo de Antônio de Miranda, preso sob a acusação de pretender fugir para o mocambo, afirmou ter entrado em contato com alguns escravos de moradores locais que haviam fugido para o referido mocambo, por intermédio do preto José, escravo de João Pereira de Lemos. Estes negros lhe perguntaram sobre o tratamento que recebia, pois eles, no mocambo, haviam sido bem recebidos: "logo que daqui fugiram como iam amofinados e Cansados da viagem os Sangravam e Purgavam e que foram tratados a galinha".

\footnotetext{
${ }^{133}$ Ofício do comandante da Praça de Macapá, para o governador e capitão-general do Estado do Grão-Pará e Rio Negro, D. Francisco de Souza Coutinho, 27/01/1791, APEP, Códice N 266: Correspondência de Diversos com os Governadores, Ano de 1791, doc. 07.

${ }^{134}$ Ofício do comandante da Praça de Macapá, para o governador e capitão-general do Estado do Grão-Pará e Rio Negro, D. Francisco de Souza Coutinho, 06/09/1791, APEP, Códice No 266. Correspondência de Diversos com os Governadores, doc. s/s.

${ }^{135}$ Carta de Diogo de Mendonça Corte Real, secretário de Estado da Marinha e Ultramar, a D. frei Miguel de Bulhões, governador interino do Estado do Grão-Pará e Maranhão, 26/05/ 1756, APEP, Códice 86: Correspondência da Metrópole com os Governadores, 1756-1778, doc. 9, p. 14.
} 
Ao serem perguntados pelo preto Miguel sobre de que se ocupavam, teriam lhe respondido "que era em fazerem Roças grandes e que os seus haveres os vendiam aos franceses porque com eles tinham comércio [...] e que estavam muito bem de sorte que o escravo de Estevam Luís da Rocha já lá tinha um Curral de gado". ${ }^{136}$ Além de cultivarem suas roças, os negros desse quilombo trabalhavam nas propriedades dos franceses, para onde iam pela manhã e voltavam à noite.

No entanto, eram os ataques às propriedades e os roubos efetivados pelos escravos aquilombados que causavam maior preocupação às autoridades portuguesas. Nesse sentido, o Senado da Câmara de Macapá propôs ao governo da capitania que retivesse na prisão os escravos desertores, capturados nos mocambos, e obrigasse seus donos a vendê-los

para diferentes Países donde nunca mais aqui apareçam porque do contrário nos ameaça outra maior ruína, porque cada um destes escravos é um Piloto para aqueles continentes de donde agora vêm e muito bem podem conduzir os que aqui hão. ${ }^{137}$

O temor dos proprietários não se limitava apenas à ameaça latente de rebelião, estendia-se também à possibilidade de perda da mão de obra escrava africana, que estaria ansiosa para passar às áreas onde não mais existia a escravidão.

Em 1795, Hilário de Moraes Betencourt, encarregado de destruir mocambos e coibir manifestações agressivas de escravos negros, oficiou ao governo do Grão-Pará, comunicando a ocorrência de um levante de negros na vila de Cametá, que o levou a colocar nesta vila uma guarda efetiva de 30 praças, nos seguintes termos:

por causa de vários tumultos e Conventículos de Pretos, que tinham já o Povo, e principalmente o Mulherio acometidos de um justo temor pelas ameaças dos referidos Pretos de que quando os Maridos viessem da

\footnotetext{
${ }^{136}$ Auto de Perguntas feito ao Preto Miguel Escravo de Antonio de Miranda a requerimento deste, APEP, Códice N ${ }^{\circ}$ 259: Correspondência de Diversos com os Governadores, 1790-1794, doc. 31.

${ }^{137}$ Representação do Senado da Câmara de Macapá ao Governo do Pará, 21/02/1793, APEP, Códice n. 259: Correspondência de Diversos com os Governadores, 1790-1794, doc. 72.
} 
Cidade as achariam, e a suas filhas prenhes sem exceção [e] que havendo qualquer resistência nelas as picariam como carne no Açougue. ${ }^{138}$

Pode-se imaginar o impacto que tal informação causou na população branca da capitania do Pará, onde só em Belém, num total de 5.492 habitantes, havia 3.492 escravos, ${ }^{139}$ depois dos acontecimentos ocorridos em São Domingos, a partir de 1793, resultantes da rebelião de escravos liderada por Toussaint L'Ouverture. ${ }^{140}$

Assim, o impacto produzido pela concessão da liberdade aos índios e pelos surtos epidêmicos que os atingiram levou ao "enegrecimento" da floresta amazônica. ${ }^{141}$ Índios e negros desenvolveram múltiplas formas de resistência à situação que lhes foi imposta, sendo que a forma mais comum foi a fuga e a organização de mocambos ou quilombos.

Entre 1752 e 1809, o que inclui todo o período do Diretório, havia 35 mocambos de índios fugidos na Amazônia colonial, espalhados pelas capitanias do Pará e Rio Negro, principalmente nas regiões de Alter do Chão, Melgaço, Nogueira, Santarém, Boim, Barcelos, Serpa, Colares, Portel, Cametá, Soure, Vila do Conde, onde foram estabelecidas as principais vilas do Diretório, o que demonstra que as fugas, também, se constituíam em formas de resistência às imposições dos aldeamentos. Na maioria das povoações citadas, entre 1762 e 1801, foram identificados dezesseis mocambos de índios e negros juntos. ${ }^{142}$

Em um processo histórico de longa duração, índios e negros vivenciaram experiências de opressão e exploração que lhes permitiram construir a consciência de dominados e tecer redes de solidariedades, que não excluíam conflitos. ${ }^{143}$ Apesar do forte controle a que eram sub-

\footnotetext{
${ }^{138}$ Ofício de 12 de setembro de 1795 ao Governo do Grão-Pará, APEP, Códice No 285: Correspondência de Diversos com o Governo, 1794 - 1796, doc. 43.

139 Recenseamento Geral do Grão-Pará (1788), Arquivo do Rio Negro, vol. I, Universidade do Amazonas.

${ }^{140}$ Cyril Lionel Robert James, Os jacobinos negros: Toussaint L'Overture e a revolução de São Domingos, São Paulo: Boitempo, 2000.

${ }^{141}$ Flávio dos Santos Gomes, "A hidra e os pântanos: quilombos e mocambos no Brasil (sécs. XVII-XIX)" (Tese de Doutorado, Universidade Estadual de Campinas, 1997), pp. 41-55.

${ }^{142}$ Gomes, "A hidra", p. 80-1.

${ }^{143}$ Sobre solidariedades e conflitos entre índios e negros ver Stuart B. Schwartz, "Tapanhuns, negros da terra e curibocas: causas comuns e confrontos entre negros e indígenas", Afro-Ásia, n. 29/30 (2003), pp. 13-40.
} 
metidos e da violenta repressão que sofriam, encontraram brechas para fazer valer as suas demandas e a sua percepção do mundo em que foram obrigados a se inserir.

Embora derrotados no processo histórico vivenciado, nunca abandonaram a condição de atores, construindo, no cotidiano de suas vidas, sua própria história, marcada por solidariedades, conflitos, negociações, concessões, alianças, proteção, ora resistindo, ora se conformando à experiência histórica que lhes foi imposta, "misturando o verde, o amarelo e o negro". ${ }^{144}$

Texto recebido em 10 de junho de 2011 e aprovado em 29 de janeiro de 2013

\footnotetext{
${ }^{144}$ Gomes, “A hidra”, p. 40.
} 


\title{
Resumo
}

O presente artigo pretende analisar o mundo do trabalho no Grão-Pará colonial durante o período pombalino, onde a tenaz resistência dos índios à disciplina de tempo e de trabalho imposta pela colonização, associada às altas taxas de mortalidade entre eles causadas pelas epidemias, intensificaram o tráfico negreiro para a capitania no século XVIII, durante a vigência da Companhia Geral de Comércio do Grão-Pará e Maranhão. A experiência colonial vivenciada por índios e negros, marcada pela excessiva exploração e opressão, levou-os a construir uma identidade de interesses e a desenvolver formas de resistência coletivas, o que justificou a radicalização das medidas repressivas por parte das autoridades coloniais.

Palavras-chave: escravidão, resistência, repressão.

\begin{abstract}
This paper aims to analyze the labor world in the Colonial Grão Pará during the Pombaline period, when Indians showed tenacious resistance to time and work discipline. Such discipline was imposed in the colonization process, associated with high rates of mortality, due to epidemics, resulting in the enhancement of the African slave trade to the captaincy in the 18th century, during the control of the Grão Pará and Maranhão General Trading Company. The Indians' and slaves' colonial experience, which encompassed excessive exploitation and oppression, led these populations to form an identity of interests, and to develop forms of collective resistance, which, thus, justified for a more severe repression by colonial authorities.
\end{abstract}

Keywords: Slavery - resistence - repression. 
